3. Historia del Derecho español 

Revista de Estudios Histórico-Jurídicos

[Sección Historia del Derecho Español]

XXXV (Valparaíso, Chile, 2013)

[pp. 257 - 294]

\title{
LA COMPETENCIA SOBRE LOS PLEITOS DE HIDALGUÍA EN LA CORONA DE CASTILla DURANTE LA BAJA EDAD MEDIA: LOS ALCALDES DE LOS HIJOSDALGO
}

[Jurisdiction over Pleitos de Hidalguía ${ }^{+}$in the Crown of Castile during the Late Middle Ages: Alcalde de Los Hijosdalgo ${ }^{++}$]

\author{
Luis Díaz de la Guardia y López* \\ Universidad de Granada, España
}

\begin{abstract}
ResUmen
El artículo, usando las normas, las antiguas fazañas y la documentación inédita de los siglos XIV y XV, estudia el problema del conocimiento jurisdiccional de los pleitos de hidalguía por los alcaldes de los hijosdalgo castellanos desde el siglo XIII al XV, que a la postre se pretendió privativo, y se relaciona éste con la actuación de otras jurisdicciones (locales, hacendísticas, de las Órdenes Militares, etc.) sobre pleitos de hidalguía en la baja Edad Media castellana.

Palabras clave

Pleitos de hidalguía - Alcaldes de los hijosdalgo - Notarios de reinos - Procuradores fiscales - Reales Chancillerías.
\end{abstract}

\begin{abstract}
Based on the norms, the past feats and unpublished documents of the 14 th and 15 th Century, this article studies the problem of the jurisdiction hearings of pleitos de hidalguía by the Castilian alcaldes de los hijosdalgo from the 13th to the 15th Century, that was finally claimed to be privative and is related to the legal actions of other (local, estates, of Military Orders, etc.) jurisdictions over pleitos de hidalguía during the Castilian Late Middle Ages.

KeYwords

Pleitos de hidalguía - Alcaldes de los hijosdalgo - Notaries of kingdoms - Public prosecutors - Royal Chanceries.
\end{abstract}

RECIBIDO el 21 de mayo y ACEPTADO el 28 de junio de 2013

* Profesor de Historia del Derecho y de las Instituciones en el Departamento de Derecho Internacional Privado e Historia del Derecho de la Facultad de Derecho de la Universidad de Granada. Dirección postal: Plaza de la Universidad s/n, 18071 Granada, España. Correo electrónico: 1diazdelaguardia@ugr.es.

${ }^{+}$Litigation to prove noble status.

${ }^{++}$The room of hijosdalgo in the chancillerías of Valladolid and Granada, which knew of the lawsuits of chivalry and the grievances that were made to the noblemen with regard to the exemptions and privileges was togado judge. 


\section{LA COMPETENCIA JURISDICCIONAL SOBRE LOS PLEITOS DE HIDALGUÍA SEGÚN LA DOCTRINA Y LA LEY EN LA EDAD MODERNA}

1. En primera instancia competía el conocimiento de los pleitos de hidalguía a los alcaldes de los hijosdalgo durante toda la existencia de este tipo de pleito, y a éstos y a los notarios de provincias hasta 1572, en que fueron sustituidos los notarios por un tercer alcalde de nueva creación al tiempo que las alcaldías se rescataban y pasaban a ser designadas directamente por la Corona ${ }^{1}$. Varias disposiciones de Enrique II, recogidas en las Ordenanzas Reales de Castilla, mandan que sean los alcaldes de los hijosdalgo los que vean los asuntos de hidalguías. "Nvestra merced $y$ voluntad es que aquellos que son o fueren notorios fijosdalgo de solar conoscido o houieren hauido sentencia en cómo son dados por fijosdalgo, según el tenor de la ley que dispone que sean dados por fijosdalgo por nuestros alcaldes de la nuestra Corte e Chancillería con el procurador del lugar donde bivieren y con el nuestro procurador fiscal [...]. Y es nuestra merced que si el concejo donde assi biuieren los que assi están en possesión de fijosdalgo los contradixeren que ninguno conozca de ello saluo que gelo vengan a demandar ante los alcaldes de lo fijosdalgo, porque ellos lo oyan e libren lo que fallaren por Derecho" ${ }^{2}$.

El establecimiento de la naturaleza privativa del conocimiento de los alcaldes de los hijosdalgo sobre los pleitos de hidalguía que se atribuye a Enrique II, fue de nuevo ordenado y reforzado por una disposición de Juan I en las Cortes de Burgos de 1379, recopilada tanto en el "Ordenamiento de Montalvo" $(4,2,8)$ como en la "Nueva Recopilación" $(2,11,12)$ y en la Novísima Recopilación, con declaración de nulidad de las sentencias de hidalguías dadas fuera de la Corte y Chancillería: "Ordenamos que el fijodalgo que no fuere dado en la nuestra Corte y Chancillería y con el procurador del lugar donde mora y con nuestro procurador, por fijodalgo, que la sentencia que por él fuere dada sea ninguna"3.

2. La jurisdicción privativa de los alcaldes de los hijosdalgo no sólo está establecida por la norma sino que es refrendada continuamente por las Chancillerías ante cualquier atisbo de intromisión por jurisdicción distinta a ellos. Los testimonios son abundantes y perseverantes, por ejemplo, el 4 de noviembre de 1495 recibía una real provisión de la Chancillería de Valladolid el corregidor de Ávila, licenciado Juan Pérez de la Fuente, prohibiéndosele conocer de asunto alguno relativo a las declaraciones de hidalguía, defendiendo la jurisdicción de los alcaldes de los hijosdalgo vallisoletanos y ordenando que en adelante se remitiese cualquier tipo de causa similar a ellos ${ }^{4}$. Del mismo modo, en una ejecutoria dada en Ciudad Real el 8 de enero de 1504, motivada por las discordias y posibles fraudes habidos en los repartimientos cacereños, se especifica por el estado de los buenos hombres pecheros que el concejo de la entonces villa de Cáceres se había atrevido "a conoçer de pleytos de fidalguías, pronunçiando por omes fijosdalgo a algunas de las personas

\footnotetext{
1 "Nueva Recopilación” (en adelante NR.) 2,11,32.

${ }^{2}$ Ordenanzas Reales de Castilla (en adelante OO. RR.) 4,2,6.

${ }^{3}$ Novisima Recopilación (en adelante Nov. Recop.) 11,27,1.

${ }^{4}$ Archivo General de Simancas, Registro 3930, 4 de noviembre de 1495, fol. 111, Bur-
} gos. 
a quien los dichos sus partes avian prendado, no lo pudiendo fazer, perteneçiendo el conoçimiento de ello a los dichos nuestros alcaldes e notario" . La respuesta de la Chancillería de Ciudad Real fue contundente, pues no solo resolvió el pleito sobre los repartimientos y la forma que habían de tener, sino que expresó que el conocimiento de las causas de hidalguía pertenecía en exclusiva a sus alcaldes y en consecuencia ordenó al concejo de Cáceres que no se entrometiera y que todos los pleitos que en dicha villa había sobre hidalguías se vieran ab initio por la Corte de Ciudad Real.

3. Siguiendo la ley y la práctica, la doctrina de la época mantiene similares postulados, así uno de los principales comentaristas de este proceso en el siglo XVI. El fiscal de Granada y oidor de Granada y Valladolid Juan de Arce de Otalora en su De nobilitatis et inmunitatis hispaniae causis de 1553 establece la jurisdicción para los alcaldes de los hijosdalgo y notarios de provincias, aún no han desaparecido estos últimos cuando escribe, de tal modo, asegura, que si causas de este estilo fuesen vistas por otros jueces serían nulas de pleno Derecho: "Viso de persona actoris, est videre coram quibus iudicibus debeant intentari istae causae. Et respondeo distinguendo aut particularis praetendit nobilitatem vel immunitatem ratione sanguinis aut praescriptionis ex titulo sanguinis et isto casu notissimum est que solamente son juezes competentes en primera instancia los alcaldes de los Hijosdalgo de Valladolid y Granada quibus solis specialiter et expresse huismodi causae sunt commissae per leyes regias... tam de iure regio propter istarunt causarum arduitatem et dignitatem deputati sunt iudices speciales que son los alcaldes de los Hijosdalgo y notarios de las provincias qui soli possunt cognoscere in prima instantia et non alii, adeo ut processus factus coram aliis sit ipso iure nullus ex defectu iurisdictionis"'.

El escribano de cámara y de los hijosdalgo de la Real Chancillería de Valladolid, Francisco González de Villegas, en el siglo XVIII y hablando de los pleitos de hidalguía, dice que: "el remedio que para todas estas cosas pueden tener los hixosdalgo para que la malizia y mala yntençión que los tales hombres pecheros hordinariamente tienen contra ellos no tenga efecto, es acudir a la sala de los señores alcaldes de hixosdalgo a quien priuatiuamente toca y perteneze el conocimiento de las tales causas y pleitos, donde se les mandarán dar diferentes prouisiones para todos estos casos" ${ }^{7}$. En esto sigue directamente a la Práctica y formulario de la Real Chancillería de Valladolid de Manuel Fernández de Ayala, del XVII, que afirma taxativamente, refiriéndose a los alcaldes de los hijosdalgo, que: "su sala fue establecida para que en ella privativamente se conociese de todos los negocios y pleytos de hidalguía de sangre $y$ no en otra parte alguna, $y$ así todos los pleitos se empiezan en primera instancia por demandas, delaciones y las demás introducciones que ay, y ningún concejo, estado

${ }^{5}$ Archivo de la Real Chancillería de Granada (en adelante ARChG), "Hidalguía", Caja 4493-72b.

${ }^{6}$ ARCE DE OTALORA, J. de, De nobilitatis et inmunitatis hispaniae causis (quas hidalguia appellant) de que regalium tributorum (quos pechos dicunt) iure, ordina, iudicio et excusatione summa, parte 3a ${ }^{\mathrm{a}}$, cap. $2^{\circ}$ (Granada, Xantus et Sebastianus Nebrissensis, 1553), fol. 31vo.

${ }^{7}$ Archivo de la Real Chancillería de Valladolid (en adelante ARChV), "Libros" 1209, fol. $1-1 v^{o}$ 
de hombres buenos ni otra junta deve reconocer a ninguna persona por hijodalgo de sangre sin que primero aya acudido a la sala".

Por contra las prácticas granadinas del procurador Juan Martínez Lozano titulada Práctica de la Real Chancillería de Granada', del siglo XVII, y del abogado don Antonio de Orejón y Haro nombrada Apuntamientos sobre la hidalguía y colección de fórmulas para todos los recursos de esta naturaleza ${ }^{10}$, del siglo XVIII, dan por conocida la competencia de los alcaldes de los hijosdalgo de manera automática, sin hacer referencia a su origen y alcance. Para los granadinos los alcaldes de los hijosdalgo son los jueces competentes naturales y por tanto se limitan a explicar sus funciones sin mayor discusión, ninguna otra jurisdicción en primera instancia es contemplada y esto intemporalmente.

A partir de todos estos testimonios de la Edad Moderna española pareciera que la jurisdicción objetivamente competente y de forma privativa en la primera instancia correspondía a las salas de los alcaldes de los hijosdalgo de ambas Chancillerías castellanas desde tiempo inmemorial, desde siempre. Conclusión que se ve reforzada en base a la lógica por el nombre de la causa y del órgano que la conoce: pleitos de hidalguía y alcaldes de los hijosdalgo. Son realidades que se muestran ineludiblemente relacionadas, unidas, pero lo cierto es que esto no fue siempre así, cuando menos en exclusiva, privativamente, recordemos que como dice Hevia la "jurisdicción privativa es la que por si sola priva a las demás del conocimiento de la causa que a ella pertenece, como es la de los jueces a quien se cometen las causas, con inhibición de ellas a los demás"11, pero es que los alcaldes de los hijosdalgo no fueron históricamente los únicos que conocieron de los pleitos de hidalguía.

\section{ORIGEN DE LA ALCALDÍA DE LOS HIJOSDALGO}

Las alcaldías de los hijosdalgo son de origen incierto, al igual que muchas otras magistraturas y oficios de nuestro pasado ${ }^{12}$. Como es sabido, el rey Alfonso

\footnotetext{
${ }^{8}$ Fernández de Ayala Aulestia, M., Práctica y formulario de la Chancillería de Valladolid (Valladolid, Imprenta de José de Rueda, 1667). Se usa aquí la edición corregida y aumentada de don José de Luyando, Zaragoza, Imprenta de Francisco Revilla, 1733, fol. 15.

${ }^{9}$ López Nevot, J. A., Práctica de la Real Chancillería de Granada. Estudio preliminar y edición del manuscrito 309 de la Biblioteca Nacional de Madrid, Granada (Granada, Comares, 2005).

${ }^{10}$ Orejón y HARO, A. de, Apuntamientos sobre la hidalguía y colección de fórmulas para todos los recursos de esta naturaleza, con la instrucción que debe dirigir los de los extranjeros, conforme a la práctica que observa la sala de los sres. alcaldes de los hijosdalgo de la Real Chancillería de Granada (Málaga, Luis de Carreras impresor, 1795). Se usa la siguiente edición Díaz de la guardia y López, L., La hidalguía a fines del Antiguo Régimen. Los "Apuntamientos" del granadino Antonio de Orejón y Haro: estudio y edición, en Espacio, Tiempo y Forma. Historia Moderna, 21 (2008), pp. 83-145.

${ }^{11}$ Hevia Bolaños, J. de: Curia philipica (Lima, 1603), se usa aquí la edición de Madrid, Oficina de Ramón Ruiz, 1797, tomo I, p. 21.

${ }^{12} \mathrm{La}$ doctrina concluye en la antigua tradición de estas alcaldías de los hijosdalgo, retrotrayéndolas a Roma o los godos, "vsitatum enim est in Hispania iam inde a Gothis, quo tempore nobiles distinguebantur a plebeis vt nobiles suos haberent iudices", GARCía DE SAAVEDRA, J., Tractatus de hispanorum nobilitate et exemptione sive ad pracmaticam cordvbensem, que est l.8, tit. 11. li. 2 noux recopillat, glosa primera (Alcalá de Henares, a costa de Juan de Sarria, 1597), fol. 23 vo.
} 
X el Sabio, en 1272, creó dos alcaldes de los hijosdalgo bajo las presiones de la nobleza, aunque posiblemente antes los hijosdalgo ya poseyesen justicias propias pero no junto al rey ${ }^{13}$. La tradición de la existencia de alcaldías de hijosdalgo, no sólo en la Corte, se plasma, entre otros testimonios, en las Cortes de Madrid de 1329, donde se ordena que uno de los dos alcaldes que debían acompañar al merino mayor de Castilla fuese hidalgo pues ya lo tenían por fuero ${ }^{14}$, y más concretamente en la siguiente petición: Otrosí, lo que me pidieron por merced que les dé alcalles fijosdalgo o adelantados para las comarcas do los suele aver. A esto vos respondo que lo otorgo do lo suelen aver" ${ }^{15}$.

Son peticiones y disposiciones que se fundamentan en el uso y la costumbre, que cierto que podía arrancar de 1272, pero que incitan a pensar en una larga tradición que se plasmó en la creación de justicias propias para el estado noble,

${ }^{13}$ Varona García, M. A., La Chancillería de Valladolid en el reinado de los Reyes Católicos (Valladolid, Universidad de Valladolid, 1981), p. 142. También recogida esta creación, entre otros, por Jordán de Asso y de Manuel en su "Prólogo" a la edición del Fuero Viejo, refiriéndose a las concesiones de Alfonso X a la nobleza en las Cortes de Burgos, Jordan DE Asso, I. - ManUeL y Rodríguez, M. de, El Fuero Viejo de Castilla, sacado y comprobado con el ejemplar de la misma obra que existe en la Real Biblioteca de esta Corte y con otros manuscritos (Madrid, Señores de Calleja, 1847), p. xxvi. Biografías ya clásicas de Alfonso X el Sabio dan visiones de conjunto sobre el enfrentamiento entre el rey Alfonso y sus reformas políticas y la oposición y rebelión nobiliaria, como Ballesteros Beretta, A., Alfonso X el Sabio (Barcelona, Ediciones El Albir, 1984); González Jiménez, M., Alfonso X el Sabio, 1252-1284 (Palencia, La Olmeda, 1993); O'Callaghan, J. F., El rey sabio. El reinado de Alfonso $X$ de Castilla (Sevilla, Universidad de Sevilla, 1999); Salvador Martínez, H., Alfonso X el Sabio. Una biografia (Madrid, Ediciones Polifemo, 2003); Valdeón Baruque, J., Alfonso Xel Sabio (Barcelona, Ediciones Temas de Hoy, 2003). Sobre el Derecho y el enfrentamiento de la nobleza y Alfonso X, véanse: SÁNCHEZ, G., Para la historia de la redacción del antiguo Derecho territorial castellano, en Anuario de Historia del Derecho Español (en adelante AHDE.), 6 (1929), pp. 282-284; Alvarado Planas, J. - Oliva Manso, G., Los fueros de Castilla (Madrid, Centro de Estudios Políticos y Constitucionales, 2004), pp. 113-123, y para la creación de alcaldes hidalgos en este tesitura véase Ibíd. p. 116.

${ }^{14}$ Colección de Cortes de los reynos de León y Castilla dada a la luz por la Real Academia de la Historia (Madrid, Imprenta de Marcelino Calero y Portocarrero, 1836) (en adelante CLC.), I: “Cortes de Madrid de 1329”, petición 11, p. 11. En la siguiente fazaña de tiempos de Alfonso $\mathrm{XI}$ se contiene la concesión de semejante alcaldía de los hijosdalgo: "Et otrosy le pidieron por merçed que commo el traya dos alcaldes fijosdalgo ordenarios en la su Corte, que mandase al su meryno mayor de Castiella que trayese otro alcalle fijodalgo consigo [...]. Et el rey mandolo asy", en SuÁrez Verdeguer, F., La colección de "fazañas" del Ms. 431 de la Biblioteca Nacional, en AHDE., 14 (1942-1943), p. 590.

${ }^{15}$ CLC., I: "Cortes de Madrid de 1329", petición 20, p. 14. Varona García, M. A., La Chancillería, cit., pp. 142-143, interpreta estas peticiones de Cortes como solicitudes del reino para reafirmar la implantación de las alcaldías de los Fijosdalgo, no obstante más parecen confirmaciones de costumbres inveteradas, pese a que es cierto que en las Cortes de Carrión de 1317 se solicita el alcalde de los hijosdalgo de Corte. Esta petición y su otorgamiento ya consta en las Cortes de Medina del Campo de 1328, CLC., I: "Cortes de Medina del Campo de 1328”, petición 11, p. 9. Apoya este origen consuetudinario de las jurisdicciones nobiliarias: Villapalos Salas, G. A, Justicia y monarquía. Puntos de vista sobre su evolución en el reinado de los Reyes Católicos : discurso leído el día 16 de junio de 1997 en su recepción pública como académico de número, por Gustavo Villapalos Salas, y contestación de José María Castán Vazquez (Madrid, Marcial Pons, 1997), p. 201. 
seguramente arbitrales ${ }^{16}$, lo que no es de extrañar habida cuenta la separación entre realidades pecheras e hidalgas en la alta Edad Media e inicios de la baja, donde los fueros locales y sus justicias mantienen con frecuencia cierta repugnancia ante el ser nobiliario y su ordenamiento jurídico, pretendiendo el allanamiento comunal al fuero, sin más derechos ni privilegios que los que la norma local otorga a sus vecinos y moradores ${ }^{17}$.

${ }^{16}$ Sobre las justicias arbitrales nobiliarias: Alvarado Planas, J. - Oliva Manso, G., Los fueros, cit. (n. 13), p. 26.

${ }^{17}$ Muchos son los fueros que son explícitos en pretender la conversión a la villanía, de facto, de los hidalgos y a que se cumpla el fuero del lugar sin que se pueda usar de otro fuero por sus moradores y vecinos. Los ejemplos son numerosos, así el rey Alfonso IX al otorgar fuero, el 12 de octubre de 1208, al concejo de Belver de los Montes, dispone: "Si fidalgus in Belveer vecinus fuerit, ille et uxor eius et filii sui tale forum habeant sicut vicini sui", en RODRÍGUEZ FERNÁNDEZ, J, Los fueros locales de la provincia de Zamora (Salamanca, Junta de Castilla y León, 1990), p. 317. Manda el fuero de Uclés dado en Toledo en marzo de 1179: "Infanzones qui venerint al Ucles populare, tales calumpnias habeant de morte et de vita quomodo alios populatores. Infanzones qui intrare in termino de Ucles de los moiones adentro, tales foros habeant quomodo alios vicinos de Ucles", en Martín, J.L: Los fueros de la Orden de Santiago en Castilla-La Mancha, en Alvarado PLANAS, J. (coordinador), Espacios y fueros en Castilla-La Mancha (siglos XI-XV). Una perspectiva metodológica (Madrid, Ediciones Polifemo, 1995), p. 195. Ejemplos que por cierto no se limitan siempre a poblaciones pequeñas. Dice el Fuero de Sahagún dado el 18 de diciembre de 1152 por el rey Alfonso VII y el abad Domingo: "Et quicumque nobilis vel cuiuslibet dignitatis in villa Sancti Facundi in propia vel aliena domo havitaverit, ipse et quicumque cum eo fuerit, habeat forum ville, sicut unuquisque de vicinis", en Rodríguez Fernández, J, Los Fueros del Reino de León, II: Documentos (Madrid, Ediciones leonesas, 1981), p. 73. Preceptos que se cumplieron -es imposible conocer su cuantía- por aquellos hidalgos que por las razones que fuesen necesitaban ser comprendidos entre los vecinos, no como simples moradores, sino como verdaderos vecinos, y vecindades que son otorgadas bajo condiciones, sometidas a veces a la temporalidad, pero que obligan a someterse al fuero del lugar y sobre todo en sus aspectos financieros y tributarios, aspecto éste que, como es lógico, poco agradaba a los hidalgos. Sirva de muestra, de que así ocurría, el siguiente documento en donde un hidalgo llamado Pedro Sánchez de Cañete se obliga, el 23 de diciembre de 1435, a contribuir a condición de ser admitido como vecino del lugar de las Majadas: "Sepan quantos este público instrumento vieren como en la çibdat de Cuenca veinte e tres días del mes de desienbre, año del nasçimiento del nuestro señor Ihesu Christo de mil e quatroçientos e treynta e çinco años, en presençia de mí Martín Lopes de Bolliga, escrivano de nuestro señor el rey e su notario público en la su Corte en todos sus regnos e de los testigos de yuso escriptos, paresçió presente Pero Sanches de Cañete e dixo que por quanto él hera vesino e se avía avesindado antes de agora en las Majadas, lugar de Sancho de Jarava, e agora como primeramente que se avesindava e avesindó en el dicho lugar las Majadas con el conçejo e omes buenos pobladores e vesinos e moradores del dicho lugar, que absentes estavan, a saber conviene por dies años conplidos primeros e avenideros de la fecha de este público instrumento e que se onbligava e obligó por sy mesmo e por todos sus bienes, así muebles como rayses, avidos e por aver por comoquier que los oy dia ha e aver deva en qualquier manera para pechar e dar e pagar con el dicho conçejo e omes buenos pobladores e vesinos e moradores del dicho lugar Las Majadas, todos los pechos e trebutos e derechos acostunbrados e perteneçientes e devidos pagar al dicho Sancho de Jarava, señor del dicho lugar Las Majadas. E por la forma e manera que el dicho conçejo e omes buenos, vesinos e moradores del dicho lugar e cada uno de ellos lo ha usado e acostunbrado e usaren e acostunbraren pagar de aqui adelante e en los tienpos pasados todos los otros pechos e derechos pertenesçientes e devidos pagar en qualquier manera que el dicho conçejo usa e acostunbra derramar entresy, asy para sus menesteres como para otras qualquier cosas que pertenesçientes y nesçesarias sean para pro común del dicho conçejo e vesinos e pobladores e moradores del dicho lugar e cada uno de ellos en todo el dicho tienpo de los dichos dies años que la dicha vesindat 
Repugnancia y enemistad que también es compartida por el estado de los hijosdalgo en lo que toca a admitir que la jurisdicción pechera y concejil conozca de asuntos de nobles: el hidalgo solo deberá ser juzgado por hidalgo. Pretensión, esta última, que llegará a mantenerse en el tiempo al continuar exigiendo la legislación de la Edad Moderna, al alcalde de los hijosdalgo de las Chancillerías, que posea condición noble ${ }^{18}$.

Así la creación por Alfonso X en 1272 de dos alcaldes de los hijosdalgo vendría a estar enclavada dentro de la creación de alcaldes de Corte propia de esta etapa de su reinado y a la vez sería reflejo de una realidad previa, la de la existencia de

a de durar. E dixo que se obligava e obligó de tener e guardar e conplir todo los sobredicho e cada cosa de ello, sopena de dos mil maravedís de esta moneda usual de Castilla, que dos blancas fasen, $e$ mil para el dicho Sancho de Jarava... De lo qual otorgó e mandó faser este instrumento público por la forma que de susodicho e declarado es. En que rogó a mí el dicho Martín Lopes, escrivano, que los escriviese e fisiese escritura e lo signase de mi signo. De que fueron testigos presentes, Garçía de Jarava e Diego de Villaguera, escudero del dicho Sancho de Jarava, e Martín Lopes de Bolliga, escrivano del rey. Fecho e otorgado fue este público instrumento en la dicha çibdat de Cuenca, día mes e año susodicho. Va escrito entre renglones e dis el dicho. E yo Martin Lopes de Bolliga escrivano e notario público susodicho del dicho señor rey en la su Corte e en todos los sus regnos fuy presente a todo lo susodicho en uno con los dichos testigos. E a pedimiento del dicho Sancho de Jarava lo escreví e dis aqui éste mío signo en testimonio de verdat. Martín Lopes, escrivano", Archivo Histórico Nacional (en adelante AHN), "Consejos", leg. 44.503.

${ }^{18}$ La ya citada fazaña de tiempos de Alfonso XI da fe de esta animadversión de los hijosdalgo a que las justicias pecheras de las villas conocieran de sus cuitas: "Et dixo Garçilaso quel pidian los fjosdalgo derecho, que los alcalles de las villas que auyan sabor de librar los pleytos de los fijosdalgo segunt las leyes, et que los fjosdalgo que non consentían en ello et que querían ser librados por el su fuero, et por esto que ponya el rey siempre dos alcalles fijosdalgo en la su Corte ordenarios que librassen por sy", en SuÁREZ, F., La colección, cit. (n. 14), p. 590. Otra fazaña del mismo manuscrito permite entrever la repugnancia a la participación pechera en asuntos de hidalguía al pretender modificar la costumbre pretendiendo que en los pleitos de hidalguía no hubiese testigos pecheros, sino solo hidalgos: "Et ally ouo grant porfia entre los fijosdalgo; los vnos disian que se auya de faser con tres fijosdalgo et dos labradores, et los otros disian que non auyan menester labrador para se faser fijodalgo lindo, mas que auya menester dose fijosdalgo lindos de padre et de abuelo, et asy se libro", Ibíd. p. 591. Animadversión de los hidalgos a ser gobernados por los pecheros que está reflejada en la división y mitad de estados a nivel concejil durante toda la baja Edad Media y la Edad Moderna, permanentemente. Por ejemplo en un pleito de 1509 sobre un repartimiento en Alcázar de San Juan, se afirma en la probanza de los hidalgos: "que este testigo bive en la villa del Corral de Almaguer e que en ella ay hidalgos e este testigo lo es, e que de dies años a esta parte, poco más o menos, que a que entran en el conçejo de la dicha villa los hidalgos de ella, ha visto que una ves se a ofresçido para hazer una yglesia se ubo de hazer un repartimiento e que la querian fazer los pecheros syn los dichos fidalgos, e que los hijosdalgo no lo consyntieron. E en fin se repartió el dicho padrón de lo que obieron de pagar los dichos fijosdalgo por sy, apartado del padrón de los pecheros, e pusyéronse cogedor fidalgo e asy pasó e que es costunbre antigua en la dicha villa que quando se coge el alcavala, que está encabeçado el pueblo, no se coge de los fidalgos onbre pechero salvo onbre fijodalgo. Eque asymismo ha visto este testigo en el dicho tienpo que se ha cogido e coge un padrón para pagar un médico que tienen en la dicha villa e, en lo que él sabe, a los fijosdalgo se coge por sy e lo coge onbre fijodalgo e aún que este testigo está agora a cargo de coger el padrón del dicho médico. Y aún sabe más este testigo que sy en la dicha villa se a de prendar algúnd onbre fijodalgo, por algunos de los repartimientos, que no da el mandamyento para ello syno al alcalde fjodalgo que es en la dicha villa", en ARChG, Caja 4982, pz. 8. 
jurisdicciones de hidalgos, más o menos temporales, encabezadas por alcaldes $\mathrm{u}$ otro tipo de justicias que servirían para dirimir conflictos entre nobles ${ }^{19}$.

Establecidas por Alfonso X, estas alcaldías de los hijosdalgo, serían reforzadas en cuanto a vitalidad y competencias en los reinados de Enrique II y Juan I, y son fruto de la fortaleza del estado noble en Castilla que busca sus signos de identidad y autonomía en el siglo XIII, creando una jurisdicción necesariamente especial frente a las ordinarias del reino que conociese de los asuntos tocantes a la nobleza ${ }^{20}$. Pero la posible revitalización y fortalecimiento de estos oficios por parte de los primeros Trastámara conlleva a la postre su sometimiento definitivo al poder regio. A las peticiones de Cortes para expandir la actividad de los alcaldes de hijosdalgo por parte de la misma nobleza, se terminará respondiendo con disposiciones de Enrique II y Juan $\mathrm{I}^{21}$. Enrique II en su ordenamiento sobre la administración de justicia de las Cortes de Toro de 1371 en que estructura su Audiencia y Corte, viene a disponer la existencia de un alcalde de los hijosdalgo junto a los alcaldes de provincias, los del rastro y el de las alzadas. Alcalde que debería oír "libre por sí mesmo los pleitos de los fijosdalgo, aquellos que fue usado e acostumbrado de librar, e que non pueda poner por si otro alcalle en quanto fuer en la nuestra Corte e que sea fjodalgo e atal que cumpla para ello e que lo ponga y por nuestro mandado"22.

El hecho de que los recopiladores de fines del siglo XV y del siglo XVI tomaran para elaborar sus leyes las de Enrique II y Juan $\mathrm{I}^{23}$, dispondrá al discurso históricojurídico a presentar y a suponer a estos soberanos y en especial al primero, como

${ }^{19}$ Alfonso X se resistió, sin embargo, a la pretensión nobiliaria de instituir unas alcaldías de los hijosdalgo y parece que éstas existieron en la Corte de forma intermitente hasta el rey Alfonso XI. Sobre esto, véase: Alvarado Planas, J. - Oliva Manso, G., Los fueros, cit. (n. 13), pp. 139-140. Y no fue a la única pretensión institucional de la nobleza a la que el rey se resistió, véase: Vázquez Campos, B., "Frontera" y adelantamientos en época de Alfonso X, en Historia, Instituciones, Documentos, 30 (2003), pp. 513-536.

${ }^{20}$ Si se admite la creación de las alcaldías de los hijosdalgo en la Corte bajo el rey Alfonso $\mathrm{X}$ en 1272 y esto bajo la presión de sus nobles, lo cierto es que estas alcaldías responderían a los mismos fines y causas que el resto de las alcaldías de la Corte creadas en 1274, pues todas ellas "son fruto esta vez de la conquista por los reinos y tierras dotadas de una cierta idiosincracia juridica del derecho a participar en la justicia de la Corte”, en GARRIGA, C., La Audiencia y Chancillerías castellanas. (1371-1525). Historia política, régimen jurídico y práctica institucional (Madrid, Centro de Estudios Constitucionales, 1994), p. 38.

${ }^{21}$ Las peticiones sobre jurisdicciones propias de hidalgos o relativas a éstas están presentes tanto en las Cortes de Alfonso X como en las siguientes y de que era costumbre propia a este estado el crear alcaldías que dirimiesen sus pleitos y defendiesen sus derechos, entre varios, son ejemplo señero las Cortes de Burgos de 1315 en la minoría de Alfonso XI. Las evidencias son diversas, así en las Cortes de 1351 consta lo siguiente: "A lo que me pidieron por merced los fijodalgo que biven en los valles de Famant de Genezo que es en la merindad de Vezio [...] dizen que solien aver alcaldes fijosdalgo, aquellos que la tierra escogie, e otrosi montaneros que guardavan sus montes e que merinavan entre ellos el merino mayor de Castiella o el que ponie la merindad de Vexio, e que les mande dar mis cartas que ayan sus alcaldes", CLC., I: "Cortes de Valladolid de 1351”, petición 26, pp. 16-17.

${ }^{22}$ CLC., I: "Cortes de Toro de 1371", Ordenamiento sobre la administración de justicia, pp. 8 y 9 .

${ }^{23}$ OO.RR. 2,4,30 y NR. 2,10,1: "Mandamos que en las nuestras Corte y Chancillerías en cada vna de ellas aya dos alcaldes de hijosdalgo, los quales no puedan poner otro en su lugar en quanto 
creadores de las alcaldías de los hijosdalgo. Pero sin menospreciar el hecho de que Enrique II reitere la existencia de las alcaldías de los hijosdalgo insertas en su reforma de la justicia, tan relevante tanto por lo que toca a la Audiencia como a la Corte, lo cierto es que estas alcaldías son previas a su reinado y a la reforma de 1371. Ya se ha visto la creación de Alfonso X para la Corte y existen testimonios de otras alcaldías de Fijosdalgo, pero, además, las leyes de Cortes nos dan noticia de que permanecían junto al rey, previamente a la disposición de 1371: "Otrossi porque fallé que en tiempo de los reyes onde yo vengo no fue uso ni costumbre de aver más de un alcalde de los fijosdalgo, tengo por bien que de aqui adelante en la mi Corte non aya más de un alcalde de los fijosdalgo, e este que oya los pleytos de los fijosdalgo, aquellos que fue usado e acostumbrado de librar, e que los oya e los libre por sí; e que non pueda poner por sí otro alcalde en quanto fuere en la mi Corte. E quando acaesciere que oviere de ir de la mi Corte, que pueda poner otro en su lugar que sea fidalgo e tal que cumpla para ello, e que lo ponga y por mi mandado"24.

De este precepto de las Cortes de Valladolid de 1351 se desprende que el uso de estas alcaldías se había prolongado en el tiempo, posiblemente desde Alfonso X, y que eran propias a la Corte mucho antes de que Enrique II diera su famosa ley. Incidiendo en esto, aunque al fin los alcaldes serían dos o más, Enrique II en 1371 viene a concluir con su odiado hermano Pedro I que sería un solo alcalde de los hijosdalgo el que residiera junto al rey, siguiendo, a tenor de las palabras de Pedro I, una tradición propia de la Corona castellana, no siendo formalmente una novedad la norma enriqueña en la tradición histórico-jurídica de Castilla. No obstante no debe ser despreciada la ley de Enrique II de 1371, si formalmente es igual a la de Pedro I y seguramente a otras de sus antecesores, el hecho de que mantenga a los de los hijosdalgo junto a los otros alcaldes en su Corte, una Corte que junto a la Audiencia y a la Chancillería va a poseer nueva estructura y nuevo significado puesto al servicio del poderío real, produce que se consagre una mutación en las alcaldías de los hijosdalgo: fueron creadas como instrumento de la nobleza levantisca que pugna con el rey por el poder y quedan convertidas, como las otras alcaldías, en instrumento del monarca dispuesto a servir al fortalecimiento de la Corona ${ }^{25}$.

Atendiendo al número de oficios acabado de referir, pese a prohibiciones y mandatos, pronto se institucionalizó la dualidad en las alcaldías de los hijosdalgo bajo Juan ${ }^{26}$, pluralidad de alcaldes que como se puede apreciar no es nueva, el

estuuieren en nuestra Corte, pero que si no residieren en la dicha Corte que pueda poner cada vno por si vn alcalde, tal que sea hijodalgo y sea hábil para ello y sean puestos por nuestro mandado".

${ }^{24}$ CLC., I: “Cortes de Valladolid de 1351”, petición 58, pp. 48-49.

${ }^{25}$ Sobre el proceso similar habido en las alcaldías de provincias, véase: GARRIGA, C., La Audiencia, cit. (n. 20), pp. 63-64.

26 "Otrosi a lo que nos pedistes por mercet que los dos alcalles de los fijosdalgo sirviesen cada anno seys meses cada uno residente en la dicha abdiencia. A esto vos respondemos que nos plase $e$ mandamos que lo fagan así so la pena que deven aver los oydores e alcalles", CLC., I: "Cortes de Briviesca de 1387 ", petición 15, p. 17. Este párrafo se ha tenido siempre como el precepto que institucionaliza los dos alcaldes, pero bien podría entenderse que ambos alcaldes, pese a las disposiciones de Pedro I y Enrique II, ya existían con Juan I e incluso Enrique II como había ocurrido con Alfonso XI, y que lo que ordena el rey Juan en Briviesca es el régimen que debían 
mismo Pedro I la denuncia en el precepto de Valladolid de 1351 lo que evidencia su existencia bajo Alfonso $\mathrm{XI}^{27}$, sin olvidar los dos alcaldes de Alfonso X, lo que puede indicar el número abundante de casos a conocer por estas alcaldías que motivaban su duplicidad, así como la atracción para los nobles de estos oficios que, como en otros, produciría que fuesen más de uno los $\operatorname{creados}^{28}$.

\section{LAS INICIALES COMPETENCIAS}

\section{DEL ALCALDE DE LOS HIJOSDALGO}

La Alcaldía de los Hijosdalgo, de origen difuso, pero tradicionales en Castilla ya para el siglo XIV y definitivamente incardinadas en la nueva justicia enriqueña, poseen un marco competencial igualmente vago para nosotros. Es de suponer que en principio debían conocer de aquellos conflictos de intereses entre nobles, entre hidalgos, sin participación de partes pecheras, ése debió ser el núcleo de sus competencias. De hecho, como manda Pedro I en las Cortes de Valladolid de 1351 y le demanda el estado de los hijosdalgo, el conocimiento de las causas entre pecheros e hidalgos no es visto por los alcaldes de los hijosdalgo, ni siquiera en principio por los otros alcaldes de Corte, sino por las otras justicias, en este caso locales: "A lo que me pidieron por merced que las querellas que dieren dellos (de los hidalgos) o de qualquier dellos aqui en la mi Corte labradores de las behetrías o de las heredades solariegas o otros qualesquier de las mis villas o de los abadengos, que les non sean demandados por los alcaldes de la mi Corte, más que los demanden ante los alcaldes de la comarca onde fueren aforadas las heredades según que lo han por fuero. A esto respondo que tengo por bien que respondan ante los alcaldes de las comarcas do las heredades son aforadas" 29 .

seguir los dos alcaldes para no dejar desatendido en ningún momento ese tribunal, lo mismo que hace en la siguiente petición con los ocho oidores.

${ }^{27}$ De que en tiempos de Alfonso XI había ya dos alcaldes de los hijosdalgo, como en tiempos de su bisabuelo Alfonso X, dan fe las fazañas del manuscrito 431 de la Biblioteca Nacional: "et por esto que ponya el rey siempre dos alcalles fijosdalgo en la su Corte ordenarios que librassen por sy; et que eran dos porque sy el vno fuese que fincasse el otro", SUÁREZ, F., La colección, cit. (n. 14), p. 590. Al número de alcaldes y su evolución a dos se ha referido, entre otros, PÉREZ DE LA CANAL, M. Á., La justicia de la Corte de Castilla durante los siglos XIII al XV, en Historia. Instituciones. Documentos, 2 (1975), pp. 383-482, en especial p. 425.

${ }^{28}$ Sobre la ambición nobiliaria medieval a los cargos del rey, véase: Moxó, S. de, La nobleza castellana en la Edad Media, en Moxó, S. de, Feudalismo, señorío y nobleza en la Castilla Medieval (Madrid, Real Academia de la Historia, 2000), pp. 294-295; y SAlaZAR y AchÁ, J. de, La casa del rey de Castilla y León en la Edad Media (Madrid, Centro de Estudios Políticos y Constitucionales, 2000), pp. 70-73.

${ }^{29} C L C$., I: "Cortes de Valladolid de 1351", Ordenamiento de los fijosdalgo, petición 14, p. 12. Sobre los asuntos que eran vistos como materia propia de los alcaldes de los hijosdalgo, véase entre otros el acercamiento que hace a esta materia Pérez de la CANAL, M. Á., La justicia, M. Á., cit. (n. 27), pp. 401-402, el que utilizando estos testimonios de Cortes y fazañas aporta una visión general de las competencias de los alcaldes de los hijosdalgo, si bien incomprensiblemente no reconoce expresamente como tal la tocante a los pleitos de hidalguía, "Las causas de hidalguía no entraban dentro del círculo de la competencia de los alcaldes de hijosdalgo; sin embargo en 1473 entendían de los pleitos sobre la revisión de las concesiones de hidalguía otorgadas por Enrique IV", Ibid. p. 402. 
Pero tampoco el conocimiento de estas causas entre solo nobles debió ser privativo, en su origen cuando menos, a los alcaldes de los hijosdalgo ${ }^{30}$. La Corte, las más de las veces, era demasiado lejana y más costosa y seguramente menos manipulable, de ahí que cualquier tipo de justicia, hidalga o no, pudiera conocer de estos litigios, así como ya junto al rey los otros alcaldes de provincia también tuviesen conocimiento de los pleitos entre hidalgos sobre cosas ocurridas fuera de la Corte, lo que, por contra, parece indicar que los únicos competentes para conocer de asuntos de nobles acaecidos en la Corte lo serían los alcaldes de los hijosdalgo. Es bajo Pedro I, en 1351, cuando se reforzará el marco competencial privativo de los alcaldes de los hijosdalgo frente a las demás justicias inclusive las de Corte, sin obviar que este ejercicio sería potestativo para los hidalgos, que cuando quisieren y les fuera más conveniente seguirían acudiendo a las justicias ordinarias: "A lo que me pidieron por merced que mande a los mis alcaldes de la mi Corte que por querellas que dan los fijosdalgo, los unos de los otros, por cosas que no sean fechas aqui en la mi Corte, que sean demandados ante los alcaldes de los fijosdalgo que son aqui en la mi Corte o ante qualquier dellos. A esto respondo que tengo por bien que si alguno de los fijosdalgo de Castiella quisiere fazer demanda a otro fijodalgo de Castiella en la mi Corte, que gelo faga ante el alcalde de los fijosdalgo de la mi Corte e non ante otro de los mis alcaldes, e el alcalde de los fijosdalgo que los oya e les guarde su fuero" ${ }^{\prime \prime}$.

Parece, pues, una competencia, la de los alcaldes de los hijosdalgo, subjetiva, en razón de los sujetos que participan en el conflicto, necesariamente nobles, no obstante también tendrán estos alcaldes conocimiento de causas en razón de la materia. Es difícil, si no imposible, precisar éstas, pero seguramente se refirieran a situaciones e instituciones en donde solo las partes podían ser nobles, propias en exclusiva de hidalgos, o, en atención de ello, directamente concedido su conocimiento en razón de la materia a los alcaldes de los hijosdalgo por Derecho consuetudinario o regio, como acontece cuando Enrique III en las Cortes de Madrid de 1391 hace competentes privativamente a los alcaldes de los hijosdalgo para casos de traición o aleve por riepto: "Otrosi si acaesciere caso de trayción o de aleve por repto, dígase ante el rey e ante el su consejo o alguno dellos e librenlo los alcaldes de los fijosdalgo con acuerdo de cavallero o del Consejo fasta la esecución" 32 .

Y dentro de estos conocimientos, por razón de la materia, se encuentran comprendidos los pleitos de hidalguía, donde las partes no son en principio necesariamente hidalgas. Muchos son los testimonios bajomedievales que

${ }^{30}$ Hasta Alfonso XI, por ejemplo, las justicias de las villas podían ejecutar a hijodalgo, de lo que protestaron al rey los nobles, solicitándole que en tales casos, en razón al sujeto, juzgase el alcalde de los hijosdalgo: "Et otrosy, que si alcalle de la villa mandase matar algún fijodalgo et el rey fallase que non le mataran commo deuya et mandase matar al alcalle por esta rason, que no era pecho el de la villa por fijodalgo; mas el fijodalgo que fuese acusado de muerte, que lo julgase el alcalle fijodalgo, et sy lo mandase matar a tuerto et el rey mandase matar al alcalle, que entonçe, era pecho fijodalgo por fijodalgo. Et el rey mandolo asy", en SUÁREZ, F., La colección, cit. (n. 14), pp. 590-591.

${ }^{31}$ CLC., I: "Cortes de Valladolid de 1351", Ordenamiento de los fijosdalgo, petición 14, p. 12.

${ }^{32}$ CLC., I: “Cortes de Madrid de 1391”, precepto 9, p. 13. 
defienden que solo pueden ser hechos los hidalgos en la Corte del rey, alegando la tradición. Principio que, obviando la posible realidad de esta costumbre en el pasado, refuerza el poder regio pues sitúa al monarca en la cúspide de cualquier honor, algo tan caro en todas las épocas y más aún dentro de la monarquía que se fortalece frente a los demás poderes del reino, frente a la misma nobleza, primero teóricamente desde Alfonso X y ya en la práctica bajo la casa de Trástamara, con Enrique II y sus sucesores.

\section{LA COMPETENCIA SOBRE PLEITOS DE HIDALGUÍA PERTENECIENTE AL ALCALDE DE LOS HIJOSDALGO} en la Baja Edad Media

Para el movimiento recopilador es la petición 19 de las Cortes de Burgos de 1379 la norma esencial que confiere la base para establecer la competencia objetiva y privativa de los alcaldes de los hijosdalgo sobre los pleitos de hidalguía ${ }^{33}$. Petición y contestación de Juan I que en realidad lo que norma principalmente son las partes del proceso, obligando para su mayor legitimidad y eficacia a que el procurador del rey interviniese en él, así como el de la localidad donde el pretendiente fuese vecino, pero que no instaura esa competencia ex novo, sino que más bien la da ya por existente y la perfecciona, volviendo a reiterar la competencia exclusiva de la Corte en estos pleitos ${ }^{34}$ : "Otrosy nos mostraron en commo algunos se fazen fijosdalgo en la nuestra Corte por falsos testigos. Et pidieron nos merçed que el que se ouiere a fazer fijodalgo, que se venga a fazer con el nuestro procurador e con vn procurador de la çibdat o villa o lugar donde fuere vezino, porque el nuestro derecho e de las nuestras çibdades e uillas e lugares sea mejor guardado. E otrosy que las sentençias que mostraren que non fueren dadas en la nuestra Corte con el nuestro procurador, que sean ningunas. A esto respondemos que nos plaze dello e mandamos e tenemos por bien que se guarde asy de aqui adelante e mandamos al nuestro chançeller

${ }^{33}$ OO.RR. 4,2,8; NR. 2, 11, 12; y Nov. Recop. 11,27,1

${ }^{34}$ No se debe atribuir sin embargo a Juan I que el procurador del rey, el futuro fiscal, interviniese por primera vez en estos pleitos en su tiempo, quizá lo destacado de este precepto es que estuviese presente el procurador del concejo, para asegurar la veracidad de los dichos de los testigos, pues no se debe olvidar que una fazaña de Alfonso XI se acusa además de a los alcaldes de los hijosdalgo y a los notarios, también a los procuradores del rey de querer novedosamente atraer los pleitos a la Corte, SuÁreZ, F., La colección, cit. (n. 14), p. 592. Participación del procurador del rey que además parece que ya se daba bajo Alfonso XI, así ocurre cuando menos en 1344, ARChG, Pergamino No 106, y que era frecuente con Enrique II, pues lo que ya sí consta en 1376 es que el pleito se libraba contra el fiscal del rey y que éste intervenía activamente a favor del fisco regio y en contra de la pretensión del hidalgo: "Sepades que paresçieron en juysio en la nuestra Corte ante Diego Fernandes de Castro, nuestro alcalle de los fijosdalgo en logar de Johan Martines de Rojas, e ante Pero Bernalt, notario de Castiella, Gonçalo Alfón, fijo de Johan Alfón, vesino de y de Medellín por sí, de la vna parte, e Rodrigo Alfón de Duennas, nuestro pocurador en nuestro nonbre de la otra parte. Et el dicho Gonçalo Alfón querelló ante los dichos nuestros alcalle e notario, e dixo que él seyendo ome fijodalgo... e luego el dicho nuestro procurador dixo que segund las condeçiones en que nos mandáramos arrendar las dichas monedas, que el dicho Gonçalo Alfón que non podría faser la dicha prueua y en Medellin, e que non sabia en que nuestra Corte fuese ome fijodalgo, que lo negaua", en ARChG, Pergamino Nº 208. 
e notarios e a los que están a la tabla de los nuestros sellos que den sobre ello nuestras cartas las que conplieren" 35 .

Esta petición, junto a la pragmática de Enrique III sobre el pechar de los pretendidos hidalgos mientras que hubiese pleito sobre sus hidalguías de 1398, también recopilada, será usada por las Chancillerías castellanas durante toda la Edad Moderna. Así se utiliza textualmente en una provisión de la Real Chancillería de Ciudad Real de 29 de julio 1504, expedida en nombre de los Reyes Católicos y dirigida al gobernador del partido de la Sierra del maestrazgo de Alcántara y a las justicias de Castuera, Benquerencia, Monterrubio, Esparragosa y Malpartida, que fue dada a petición del fiscal de Granada, bachiller Lope de Lodio, y del regidor de Castuera, Diego de Alcántara, pues "querían enpadronar e prendar a çiertas personas, por ende que les pedian en nonbre de los dichos conçejos les mandasen dar nuestra carta para las justiçias de la dicha villa e para vos el dicho governador para que diésedes todo favor e ayuda a los procuradores de los dichos conçejos para que pudiesen enpadronar e prendar a los que se desyan hidalgos e se sustrayan de pechar en los dichos pechos reales e conçejales para que pechasen e contribuyesen”. La orden para que se les diese favor fue dada, insertas la petición de Juan I y la pragmática de Enrique III, pero de igual modo y fundándose en la primera, se les ordenaba a las justicias que no se entrometieran en pleitos de hidalguías, para lo que no tenían competencia: "No vos entremetiendo en conosçer ni conoscades de los dichos pleitos tocantes a hidalguías, en dar en ellos sentençias ni mandamientos, ni en quanto al conosçimiento ni determinaçión de ellos en propiedad e posesyón, salvo quanto fuere a dar el dicho favor, ca nos por esta nuestra carta por la presente vos ynibimos e avemos por ynibidos" 36 .

${ }^{35}$ CLC., II: "Cortes de Burgos de 1379", petición 19, pp. 293-294.

${ }^{36} \mathrm{La}$ real provisión no solo trae insertos los traslados de ambas leyes, aquí se recoge ahora la de Juan I, sino que también ordena que se guarden y cumplan: "E por los dichos nuestros alcaldes e notaryo vista la dicha petiçión e por quanto sobre razón de lo en ella contenido e de quales personas han de gozar de la dicha fidalguía e quales no, el señor rey don Juan, de gloriosa memoria, fizo una ley e asymismo el señor rey don Anrrique dio una su carta premática, su thenor de las quales es éste que se sygue... Otrosy nos mostraron en cómo algunos se fasyan fijosdalgo con falsos testigos e pydiéronnos por merçed que sy se uviesen de fazer fijosdalgo que se vengan a fazer con el nuestro procurador fiscal e con un procurador de la tal çibdad, villa o lugar donde fuere veçino, porque el nuestro derecho e de las nuestras çibdades e villas sea mejor guardado. E otrosy que las sentençias que mostraran que no fueren dadas en la nuestra Corte, con el nuestro procurador fiscal, que sean ningunas. E a esto respondemos, que nos plaze de ello e mandamos e thenemos por bien que sea guardada e asy de aqui adelante mandamos al nuestro chançiller e notarios e a los que están a la tabla de los nuestros sellos que den sobre ello nuestras cartas, las que cunplieren y los que fueran dados por fijosdalgo en la nuestra Corte con el nuestro procurador fiscal, sy los conçejos dixeren contra ellas que no son verdaderas, más que son pecheros e fijos e nietos de pecheros, que lo muestren en la nuestra abdençia porque los nuestros oydores libren como fallaren por Derecho, porque los nuestros derechos sean guardados. E proveyendo sobre lo en la dicha petiçión contenido mandaron dar e dieron ésta nuestra carta para vos en la dicha raçón, e nos tovímoslo por bien. Por la qual mandamos a vos el dicho governador e al dicho vuestro theniente del partido de la Serena del maestradgo de Alcántara e a vos los dichos juezes e justiçias e a cada uno de vos, que veades la dicha ley e pramática en esta dicha nuestra carta incorporadas, e vistas, las guardades e cunplades e fagades guardar e conplir agora e de aquí adelante en todo y por todo, bien e conpliedamente segúnd que en ellas y en cada una de ellas se contiene", en ARChG, "Hidalguías", "Benquerencia", Caja 4493, pz. 67. 
Pero, pese a lo dicho, más bien parece que la competencia objetiva ya estaba atribuida, con anterioridad a Juan I, a los alcaldes de los hijosdalgo, como ha puesto de manifiesto el profesor Garriga utilizando una carta del rey Enrique II de 1374 dirigida a Murcia, publicada por el Prof. Pascual, en la que se defiende este conocimiento privativo para los alcaldes de los hijosdalgo desde antiguo ${ }^{37}$. Y, más allá de Enrique II, habría que retrotraer esta competencia sobre los pleitos de hidalguía a tiempos de Alfonso XI pues en una fazaña de ese reinado se acusa a los alcaldes de los hijosdalgo de atraer para sí el conocimiento de estos procesos de forma novedosa, lo que por otra parte se critica pues la lejanía de la Corte restaba fiabilidad a los pleitos: "Mas agora con cubdisçia los alcalles de los fijosdalgo et los notarios et los procuradores del rey fasenlos yr alla a que se fagan fijosdalgo, et nin conoscen aquellos que juraron si son peones o sy son fijosdalgo, nin nunca se gana carta de pesquisidor, et por esta rason se facen muchos yerros" 38 .

Por lo demás, ya en 1344 encontramos evidencias documentales en que el alcalde de los hijosdalgo sentencia, acompañado de "ommes buenos letrados, sabidores de fuero e de derecho", no del notario, sobre un pleito de hidalguía. Se trata, por ejemplo, del pleito habido en la Corte de Alfonso XI entre Juan Fernández de Ahumada, vecino de Sevilla en la colación de Santa María Magdalena, y el procurador sustituto del rey Juan Sánchez de Castro, sobre la hidalguía del primero y que fue sentenciado por Día Sánchez de Rojas, "nuestro alcalle de lo fijosdalgo de los nuestros reynos". Pleito del que se libró carta ejecutoria, en Algeciras, el 29 de marzo del mencionado año de 1344: "En rasón de demanda que el dicho Johan Fernandes puso ante el dicho Día Sanches, nuestro alcalle, contra el dicho Johan Sanches, nuestro procurador en nuestro nonbre, e en reconoçimiento al echo dixo que él seyendo omme fijodalgo de padre e de abuelo e de quinientos sueldos, que los cojedores que cojen e recaudauan los nuestros pechos que le demandauan que pechase en ellos... non le guardando el preuillegio e franquesas e libertades que an los fijosdalgo de nuestro sennorio e pidió al dicho Día Sanches, nuestro alcalle, que por su sentençia pronunçiase, declarase ser omme fijodalgo e que por esta misma sentençia mandase al dicho Johan Sanches, en nuestro nonbre, que de aqui adelante los nuestros cojedores que ouiesen de cojer e de recabdar los nuestros pechos que le non demandasen pecho nin pechos en ninguna manera que fuese nin le costriniesen a los pagar porque era omme fijodalgo" 39 .

Que existía este conocimiento por los alcaldes de los hijosdalgo, cuando menos desde Alfonso XI, es una evidencia que no se puede negar, no obstante existen también otras realidades que difieren de ésta y que impulsan a pensar que la competencia no era privativa, si bien las disposiciones de Enrique II y Juan I, y quizá otras anteriores desconocidas, lo pretendieran. No resulta extraño que en

${ }^{37}$ Garriga, C., La Audiencia, cit. (n. 20), p. 65. El documento en Pascual Martínez, L., Documentos de Enrique II (Murcia, Academia de Alfonso X el Sabio - CSIC, 1983), p. 235. Los cogedores de las monedas de Murcia habían protestado al rey sobre el conocimiento de estas causas por las justicias locales y el rey amparó a los cogedores, sin embargo como se verá no se mantuvo en el tiempo esta prohibición.

${ }^{38}$ SuÁreZ, F., La colección, cit. (n. 14), p. 592.

${ }^{39}$ ARChG, Pergamino, No 106. 
un proceso de fortalecimiento del poder regio, como el que se inicia en el siglo XIII y que se desarrolla con pujanza en los siglos XIV y XV, la monarquía quisiera atraer para sí unos procesos de naturaleza tan delicada y que tanto le podían importar, pues teóricamente la convertían en única generadora y reconocedora de nobleza, así como la dotaban de un instrumento sumamente importante para controlar a un grupo que se pretendía exento y privilegiado, en perjuicio, muchas veces, de sus intereses.

\section{Competencia SOBRe los Pleitos de hidalguía POR PARTE DE OTRAS JURISDICCIONES Durante la Baja EdAd Media}

El Fuero Viejo en su libro I, título $6^{\circ}$, ley $18^{\mathrm{a}}$ viene a reglar el pleito de hidalguía desde una óptica consuetudinaria, presentando un pleito en el que interviene un fiel puesto por ambas partes y en el que juzga un alcalde, pero no un alcalde de Corte o de los hijosdalgo, sino un simple alcalde, normalmente local como la mayoría a los que hace referencia este texto: "Esto es fuero de Castiella: que si algúnd ome contradijier que no es fijodalgo, e aquel a quien contradice dijier que lo es, dévese facer fijodalgo con cinco testigos, los tres fijosdalgo e los dos labradores, o con dos fijosdalgo e tres labradores sin jura. E este dicho quellos dirán, dévelo oir el fiel, que es dado de amas las partes, estando amas las partes delante. E este fiel deve tornar los dichos de los testigos al alcalle que judga el pleito, e para esto an nueve días de plaço" ${ }^{40}$.

Este precepto del Fuero Viejo induce a considerar que los pleitos de hidalguía, aquellos procesos destinados a atestiguar la condición noble o pechera de un individuo, independientemente de la causa que llevara a inquirir por tal calidad, eran vistos desde antiguo por cualquier justicia, no solo los alcaldes de los hijosdalgo o las justicias de la Corte, y esto desde luego antes de la creación de aquellos, pero también más tarde, como la realidad concluye en ello ${ }^{41}$. Por ejemplo, en Aguilar de la Frontera su alcalde sentenció un pleito el 8 de marzo de 1350 sobre la hidalguía de Sancho Martín, al cual los cogedores le exigían que contribuyese en el repartimiento de la moneda forera, de la siguiente manera: "Sepan quanto esta carta vieren como ante mi Joan Pérez de Párraga, alcalde que soy puesto en Aguilar de la Frontera para librar los pleitos de las monedas foreras [...] binieron en juiçio de

${ }^{40}$ Fuero Viejo (en adelante FV.), 1,6,18. Este precepto está igualmente recogido, comprensiblemente, en el "Pseudo Ordenamiento II de Nájera", en su título 80, igualmente en el Fuero de los Fijosdalgo y las fazañas del Fuero de Castilla, precepto 30, también en el "Pseudo Ordenamiento de León”, precepto 26, y en el Fuero Antiguo de Castilla, precepto 8, Alvarado Planas, J. - Oliva Manso, G., Los fueros, cit. (n. 13), pp. 386, 429, 460 y 475, respectivamente.

${ }^{41}$ Antes de las leyes de Enrique II y de Juan I, pero después de la de 1371, en Murcia conocían los pleitos de hidalguía las justicias locales, lo que es muestra de un estado general propio de la mayor parte de la Corona de Castilla: "Por numerosas protestas surgían en la recaudación y convenía eliminar a los que cometían fraude. Para ello el adelantado de Murcia prescribió que serían considerados hidalgos todos aquellos que hubieran sido reconocidos como tales por cualquier alcalde o juez que ejerciera en Murcia hasta la fecha y que proporcionaran la prueba escrita", esto ocurría en 1372; véase: Menjot, D., Fiscalidad y sociedad. Los murcianos y el impuesto en la baja Edad Media (Murcia, Academia de Alfonso X el Sabio, 1986), p. 231. 
la una parte Ordoño Gonçález e Miguel Sánchez, coxedores de la moneda forera [...] e de la otra parte Sancho Martín, hijo de Sancho Fernández [...] e el dicho Sancho Martín en respondiendo dixo que no era tenudo de ge las dar porque deçía que el dicho Sancho Fernández, su padre, era ome fijodalgo [...] e yo el dicho Joan Pérez, alcalde, pregunté a este Sancho Martín si quería probar esto que los dichos Ordoño Gonçález e Miguel Sánchez le negauan e él dixo que sí [...] e yo el dicho alcalde bisto los dichos de los testigos [...] e yo el dicho alcalde bisto e oydo todo esto que dicho es e juzgándo dolo por quito de los ocho marauedis [...] fecha la carta en Aguilar, ocho días de março, era de mil y treçientos e ochenta e ocho año" "42.

De hecho esta fazaña, en que se critica la intervención de los alcaldes de los hijosdalgo en estos pleitos, expresa claramente que los alcaldes de las villas tenían competencia para conocer de los pleitos de hidalguía y describe como regla general del proceso, coincidiendo con un precepto del Fuero Viejo, acerca de cómo la justicia local había de sustanciar el pleito: "Esto es regla general: Et quando otro alguno es acusado por el cogedor del rey o del sennor de la tierra donde viene o de su conceio, ase de faser fijodalgo con çinco ommes, los tres peones et los dos fijosdalgo, o con tres fijosdalgo et dos peones; et estos an de ser del alfos donde el viue, et los fijosdalgo que sepan su fidalguya et de su padre et de su abuello, et los peones que sepan si el o su padre o su abuelo pecho con ellos. Et sy aquel que se quisiere faser fijodalgo non fuese natural del alfos do le demandan el pecho, el alcalle ante quel demandaren el pecho el si dixiere que se quiere faser fijodalgo alli donde es natural que el alcalle quel de su carta para el alcalle de la villa o del alfos donde el dise que el es natural, en quel resçiba aquella muestra que le quiere faser de su fidalguía et que gella enbie signada et çerrada por que la el vea et libre lo que fallase por derecho. Et el cogedor del reyo el que coge los derechos del sennor de la villa o el conçeio que le demandare el pecho puede ganar carta del rey de pesquisa para saber si testiguaron uerdat o non aquellos que le fisieron fijodalgo, et sy fallaren que non testiguaron uerdat a el valerle a mas los que le testiguaron los fijosdalgo seran pecheros et los peones seran quintados"43.

Muchos son los testimonios en que todo tipo de justicias, sobre todo locales, ven estos procesos. Más teniendo en cuenta que las exenciones de los nobles estaban directamente en pugna con cualquier tipo de repartimiento y que los repartidores que hallaban oposición a sus actuaciones, por parte de los que se decían hidalgos, necesitaban de rápidas soluciones jurisdiccionales, lo necesitaba el rey mismo u otras instancias para el buen fin de los pedidos, lo que no era fácil de conjugar con la dilatada espera de un proceso en la lejana e itinerante Corte. Por ejemplo Lope Álvarez, comendador mayor de León de la Orden de Santiago, sentenciará en la villa de Segura el pleito habido entre el hidalgo Gonzalo Vázquez y el arrendador de las monedas de 1429, Gonzalo Muñoz, haciéndose competente sin obstáculo alguno en una causa de hidalguía y sentenciando el 19 de abril de 1431: "Sepan quantos esta carta de sentençia vieren como en la villa de Segura,... ante el onrado sennor don Lope Aluares, comendador mayor de León, justiçia mayor en la dicha tierra

${ }^{42}$ Traslado del siglo XVII, custodiado en el archivo familiar del notario don Joaquín Zejalbo Martín, cuya gentileza agradezco tanto por este documento como por otros que me ha hecho notar.

${ }^{43}$ SuÁreZ, F., La colección, cit. (n. 14), pp. 591-592. 
de León,... paresçió Gonçalo Munnos, escriuano, vesino de la dicha villa, por abtor, $e$ Gonçalo Vasques, vesino de Arroyo de Molinos, por parte reo, e dixeron que al dicho sennor comendador mayor que por quanto su merçet avía dado por jues a Myguel Sanches, veçino del Arroyo de Maestre, en un pleito que ellos an en uno sobre rasón de treçe monedas que el dicho Gonçalo Munnos, escriuano, demandó al dicho Gonçalo Vasques del anno que pasó de mil e quatroçientos e veynte e nueue annos que el dicho Gonçalo Munnos fue arrendador. Sobre lo qual dixeron que trabtaron pleito a tanto fasta que concluyeron e pidieron sentençia, el dicho abtor disiendo que el dicho reo le era deuido e obligado a le dar e pagar las dichas trese monedas, e el dicho Gonçalo Vasques respondiendo que non avía porqué pagar las dichas monedas por ser omme fijodalgo notorio... El qual dicho proçeso, luego los sobredichos, presentaron ante el dicho sennor comendador mayor, e así presentado las dichas partes pedieron al dicho sennor comendador mayor que tomase el conosçimiento del dicho pleito e lo librase. E luego el dicho sennor comendador mayor dixo que a pedimiento de las dichas partes tomava el conosçimiento de dicho pleito en el estado en que estaua... estando el dicho sennor comendador mayor en abdiençia en esta villa do la acostunbra faser, presentes las dichas partes, dió esta sentençia que se sigue: fallamos que segund los méritos de esta cabsa que el dicho Gonçalo Vasques prouó conplidamente su intento conuiene saber ser omme fijodalgo, por ende pronunçiamos su entençión por bien prouada" ${ }^{4}$.

De la misma manera, en Murcia, a la que en 1374 Enrique II prohibiera sentenciar los pleitos de hidalguía, se conocían de estos procesos por las justicias locales en la primera mitad del siglo XV, concretamente en 1436, y esto en virtud de una carta posterior dada seguramente por el mismo monarca. Ese año de $1436 \mathrm{el}$ alcalde ordinario de Murcia, Sancho Ruiz de Sandoval, juzgó el pleito de hidalguía sobre la nobleza de Alonso Yáñez de la Ballesta, al que le había sido demandada su hidalguía por el arrendador de las diecinueve monedas que el rey había ordenado recaudar en 1435. Yáñez de la Ballesta se declaraba exento como hombre hijodalgo notorio de sí, su padre y su abuelo y de este modo sería declarado por el alcalde ordinario murciano el 16 de junio del referido año de 1436 y por lo tanto fue dado por libre de contribuir: "Sepan quantos esta carta sentençia en pública forma bieren como yo Sancho Ruiz de Sandobal, alcalde urdinario de la mui noble e mui leal çiudad de Murçia... fallo que por los testigos e recados dados e presentados por el dicho Bartolomé Rodrigues de Baeça, en nombre del dicho Alonso Yáñez de la Ballesta, se prueba, es cosa probada e cosa cunplidamente el dicho Alfonso Yánez de la Ballesta ser ome fixodalgo notorio de padre e de agüelo e estar en tal posesión e notoridad de diez e beinte años e más tienpo. E que según el tenor e forma de la carta que el rei don Anrique, que Dios aya, dio a esta çiudad sobre semexantes notorios fixosdalgo, yo puedo e debo ser juez para conocer de ello e conociendo fallo que lo debo dar e doi por libre e quito de las dichas monedas contra él pedidas" ${ }^{45}$.

Esta actuación jurisdiccional local en pleitos de hidalguía era además reconocida por ley pero también por costumbre desde tiempo inmemorial, poseyendo eficacia que superaba en su aplicación a la causa que la había motivado, siendo

${ }^{44}$ ARChG, Pergamino 92.

${ }^{45}$ ARChG, "Ballesta, Fernando de la y Alonso Yáñez de la Ballesta”, n. "Alhama”; vo Mula. 1600; D. (303-345-89). 
estas sentencias respetadas y cumplidas allende el marco concreto del repartimiento en cuestión, pues poseían eficacia erga omnes y por todos era aceptada su validez como principio. Así las Chancillerías acatarán la validez probatoria de estas sentencias y la misma Corona, directamente, las reconocerá, de lo que es muestra, de ambas cosas, la carta de confirmación dada por los Reyes Católicos, datada en la Puebla de Guadalupe el 15 de enero de 1479, de otra carta de confirmación del maestre de Alcántara Gutierre de Sotomayor de una sentencia de hidalguía, pronunciada por el alcalde ordinario de Gaete de 4 de agosto de 1416, a favor de los hermanos García Morillo. Y carta de confirmación que está contenida como prueba escrita, admitida como válida por los alcaldes de los hijosdalgo de la Chancillería de Valladolid, en la ejecutoria de hidalguía de 24 de septiembre de 1596 expedida en favor de Juan Morillo, vecino de Castromocho y originario de Belalcázar: "Don Fernando e doña Ysabel, rey e reyna de Castilla [...] bimos una carta de sentenzia e confirmazión de don Gutierre de Sotomayor, maestre que fue de Alcántara [...] su tenor es éste que se sigue: don Gutierre de Sotomayor, maestre de la cavallería e horden de Alcántara [...] bimos una escriptura de sentenzia [...] el tenor de la qual carta es como se sigue: Sepan quantos esta carta bieren como ante mí Diego Sánchez, alcalde de la villa de Gaete, estando en juizio [...] parezió ante mí, el dicho alcalde, de la una parte Pedro Garzía e Rui Garzia, hijos de Gonzalo Garzía de Morillo [...] e de la otra parte Gonzalo Garzía, hixo de Diego Sánchez, coxedor e recaudador que es de la moneda forera [...] e yo el dicho alcalde vista la demanda [...] e visto en como los dichos Pedro Garzía e Rui Garzía dixeron que no abía porqué pagar la tal moneda forera ni otra alguna por quanto ellos eran hixosdalgo [...] abiendo mi acuerdo con honbres buenos e sabidores en fuero y en Derecho, juzgando mando que el dicho [...] coxedor que dé e torne las dichas prendas [...] en quatro de agosto [...] de mil e quatroçientos y diez y seis años [...]. Por quanto nos somos ynformados e zertificado el ser hombre hijodalgo ... nuestra merced e boluntad es de la confirmar [...] esta dicha sentenzia [...] en primero día de henero [...] de mil e quatrozientos e quarenta e zinco [...]. E nos por esta nuestra carta bos confirmamos e aprobamos [...] dada en la Puebla de Guadalupe a quinze días de henero, año del nazimiento de nuestro señor Jhesu Christo de mil e quatroçientos e sesenta (sic) ${ }^{46}$ e nuebe años. Yo el rey. Yo la reyna" ${ }^{47}$.

En este mismo sentido, redundando en la transcendencia jurídica y universal de estas actuaciones jurisdiccionales, la sentencia de 1436 dada por el alcalde ordinario de Murcia en favor de Alonso Yáñez de la Ballesta fue respetada y tenida por evidencia legítima para tener a los de este linaje por hidalgos notorios y a su tenor Fernad Yáñez de la Ballesta fue excluido de los repartimientos de la villa de Mula como aconteció en el realizado el 6 de abril de 1446 o Rodrigo de la Ballesta en el repartimiento de la Hermandad de 1495, el cual el 12 de agosto de 1481

\footnotetext{
${ }^{46}$ Error del escribano al realizar en el siglo XVI el traslado del privilegio. La intitulación, no siendo posible el año de 1469 con Fernando e Isabel como reyes de Castilla, parece indicar que se trata de 1479 pues constan los Reyes Católicos todavía como príncipes de Aragón, ya que aún estaba vivo Juan II de Aragón que fallecería cinco días más tarde a la data de esta carta.

${ }^{47}$ ARChV., "Registro de ejecutorias", caja 1817.0001.
} 
ya había hecho que el concejo de Mula acatase la sentencia de su antepasado y que lo tuviese por hidalgo ${ }^{48}$.

Se puede observar de lo aquí dicho que posiblemente hasta Alfonso XI los alcaldes de los hijosdalgo no tuvieron conocimiento, cuando menos continuo, de los pleitos de hidalguía y que el conocimiento mayoritario de este tipo de procesos fue competencia o bien de tribunales arbitrales o mejor de las justicias locales. Actividad que como se ha visto, la de la participación de justicias locales en los pleitos de hidalguía, no desaparece tras Alfonso XI, sino que convive con la de los alcaldes de los hijosdalgo, ciertamente en pugna, hasta cuando menos el siglo XV.

\section{INTERÉS JURISDICCIONAL REGIO POR LA NATURALEZA TRIBUTARIA} DE LOS PLEITOS DE HIDALGUÍA

Todo lo cual no impide que los hidalgos fueran creados por el rey en la Corte a través de privilegio o simple reconocimiento, como por otra parte no solo se mantuvo esta práctica de la creación regia de nobles en la Edad Media, sino también en la Moderna pese a las protestas de las Cortes ${ }^{49}$. El rey es fuente de honores y encarnación de la justicia y como tal puede recompensar y reconocer por medio del ennoblecimiento a cualquiera de sus vasallos ${ }^{50}$.

${ }^{48}$ ARChG, "Ballesta, Fernando de la y Alonso Yáñez de la Ballesta”, n. "Alhama”; vo Mula. 1600; D. (303-345-89).

${ }^{49}$ Ya en las Cortes de Ocaña de 1469 se solicita que se revoquen las mercedes de hidalguía de Enrique IV, lo que sería el inicio de una larga lista con semejantes peticiones, por ejemplo en las Cortes de 1518 se solicita que no se den hidalguías a labradores ricos o en las Cortes de Valladolid de 1523 consta: "Otrosy, porque se han dado algunas cartas de privillejos de hidalguias y hesençiones por dineros a los que las procuraron e otras se an dado syn justa cabsa e syn aver preçedido méritos ni serviçios y es daño de los pueblos y pecheros, que Vuestra Magestad las revoque e aya por revocadas las tales merçedes e previllejos, aunque las Vuestra Magestad confirmado y de aqui adelante no se den ni conçedan, porque ansy se condenó en otras Cortes. A esto vos respondemos que de aqui adelante no mandaremos dar hidalguías, salvo conforme a las leyes de nuestros reynos y en las pasadas mandamos a los del nuestro Consejo que hagan justiçia, syn embargo de qualesquier remysiones y ya avemos revocado las hidalguías que no se dieron por justas causas", en CLC., Nuevo IV: "Cortes de Valladolid de 1523", fol. 371.

${ }^{50}$ Por ejemplo el caballero portugués Martín Esteban de Mollos acudió ante el rey Alfonso XI quejándose de haber sido afrentado por el rey de Portugal como alevoso y solicitó al castellano favor para que, si no lo consideraba agraviado y deshonrado como alevoso, lo declarase por hidalgo, "et si por ventura non lo meresçe ser, que mandedes que en vuestra tierra que aya my onrra et mi calonnya, como otro fijodalgo" y "el rey touo por bien que fuese asi, que el cauallero ouyese su onra en su tierra segunt otro fidalgo", en SUÁREZ, F., La colección, cit. (n. 14), pp. 587-588. Es el rey reconocido como fuente de honores, como instancia legítima para hacer hidalgos, potestad que se ve plasmada por excelencia en los privilegios de hidalguía: "Don Anrique y por la graçia de Dios rey de Castilla de Leon de Toledo... porque a los reyes y prínçipes perteneçe remunerar aquellos que continuamente lo sirven e son çerca dellos e les fazer merçed asi dándoles dones como honrándoles e clarificándoles sus personas e linage en honores a que puestos en aquellos ayan mayor ánymo de los servir e loar exerçitar en buenas e loabres costunbres e dotrinas e asi mismo por quanto los que bien y fielmente sirven a los reies e prinçipes deven ser a sus deçendientes e generaçión comienço e acatando los muchos e buenos e leales serviçios que vos Juan Moreno mayorar de nuestra señora Santa María de Guadalupe 
Pero lo que es claro es que el "facerse fijodalgo" a través del contencioso fue abundantemente visto por los jueces locales ${ }^{51}$ y que el conocimiento de los pleitos de hidalguía por los alcaldes de los hijosdalgo, en tiempos de Alfonso XI, no solo debe observarse como basado en la simple codicia de estos, como dice la fazaña, para enriquecerse y disfrutar de mayor poder, sino que se debe fundar también en el proceso de fortalecimiento monárquico. A la monarquía le era caro este tipo de pleito a través del cual muchos se libraban de contribuir de sus pedidos y monedas, y una monarquía cada vez más fuerte que cada vez necesita de más recursos, como lo es la de la baja Edad Media, necesariamente estaba abocada a controlar estos reconocimientos de nobleza, tanto por interés económico como político. Sin embargo, como dice la citada fazaña, la lejanía de la Corte potenció igualmente el fraude e hizo necesarias medidas como las de Enrique II pero sobre

me avedes hecho e fazedes de cada día e la fedelidad e lealtad que en vos el dicho Juan Moreno e hallado en las cosas que de vos confié e por mis serviçios avedes fecho e de vuesa fidelidad e lealtad my merçed y boluntad es que vos e vuestros hijos que hasta aqui avedes avido e ovier desde aqui adelante e todos los otros vuestros deçendientes que de vos e dellos e de cada vno e qualquier dellos fueren o vinyeren para siempre gamas seades y sean avidos y tenydo por omes hijosdargo de solar conoçido e de vengar quinientos sueldos $e$ ayades e goçedes e vos sean guardadas todas las onras graçias e franquezas $i$ esençiones e preminençias e prerrogativas e ymunydades e todas las otras cosas e cada vna dellas que an e gozan e deven gozar los otros omes hijosdargo notorios de solar conoçido asy por costunbres e fueros e façañas de España como por la leies dellos... e quiero y mando y es mi merçed que vos e los dichos vuestros hijos e vuestros deçendientes e suyos e de cada vno dellos seades y sean tenydos y deputados por omes hijosdargo ábiles e yndóneos e sufiçientes bien así como si vos ellos fuesedes engendrados e procreados de omes hijosdargo de solar conoçido $e$ de vengar quinyentos sueldos e podades afiar e desafiar retar y ser retados y hazer pleito omenage y lo reçibir asi por fortalesa villa o castillo como por otro qualquier de qualquier calidad e misterio que sea e podades entrar en canpo e fazer todos los otros avtos asy de sustançia como de solenydad que los otros omes hijosdargo de los dichos mis reynos de solar conoçido e devengar quinientos sueldos puedan y devan hazer e que seades avido e tenido por ygual dellos sin reproche macula ny ojeto alguno que vos pueda ser opuesto ansi en juizio como fuera del lo qual todo y cada cosa que en contrario sea e ser pueda de hazer o allegar yo de mi propio motuo e çierta çiençia e poderio real absuluto de que en esta parte quyero usar e uso despenso con ello e alço e quito de vuestra persona y de los dichos vuestros hijos e diçendientes e de cada vno de vos e dellos toda obleçion e suplo qualesquier defetos que vos pudiesen ser ofuesen puestos e que se requerian e devan suplir para validaçion e corroboraçion desta merçed que vos yo hago que vos sea guardada no enbargante qualesquier leyes fueros e derechos e hordenamientos e prematicas esenciones vsos y costunbres e estilos e haçañas de ... sobresto mando al my chançiller e notarios e a los otros ofiçiales que estan a la tabra de los mi sellos que vos den e libren e pasen y sellen mi carta de previlegio la mas firme y bastante quen la dicha razon menester ovierdes para que vos vala y sea guardada ... dada en Praçençia a ocho días del mes de março año de nuestro Salvador Jesu Christo de mill e quatrozientos e sesenta e ocho años yo el rei yo Juan de Oviedo secretario del rei nuestro señor la fize escrivir por su mandado", en ARChG, cabina 301, legajo 32, pza. 17.

${ }^{51}$ Otros ejemplos de la actividad sobre pleitos de hidalguía por jurisdicciones distintas a los alcaldes de los hijosdalgo durante la baja Edad Media en la sentencia dada por las justicias locales de Ocaña sobre la hidalguía de Esteban Sánchez, vecino de Ocaña, de 12 de febrero de 1395; la sentencia del alcalde ordinario de Sevilla, Gonzalo González de León, sobre la hidalguía de Pedro García de Ahumada, de Sevilla a 27 de octubre de 1406, en ARChG, Pergamino 107; la sentencia del prior de la Orden de San Juan, fray Rodrigo de Luna, sobre la hidalguía de Luis Fernández de Toro, vecino de Lora del Río, de 10 de octubre de 1431, en ARChG, Pergamino 252; la sentencia del corregidor de Badajoz, Ruy Fernández de Córdoba, sobre la hidalguía de Francisco Fernández de Bobadilla dada en Badajoz el 21 de marzo de 1487, en ARChG, Pergamino 249; etc. 
todo la de Juan I de 1379, de Burgos, que ordena la presencia del procurador del rey y sobre todo también el del concejo, única forma habida para evitar en lo posible lo que la fazaña de Alfonso XI denunciaba, que los testigos, no controlados ni conocidos por el tribunal de la Corte, pudieran testificar falsamente. De ahí la defensa de la pretendida competencia privativa para los alcaldes de los hijosdalgo y de ahí posiblemente también, de la trascendencia hacendística de los pleitos de hidalguía, la participación de los notarios mayores en los pleitos de hidalguía, los que cumulativamente junto a los alcaldes de los hijosdalgo conocieron hasta el siglo XVI, en primera instancia, de estas causas.

Un tribunal que ya no era simplemente una exigencia nobiliaria impuesta al rey, sino un tribunal al servicio del monarca, incardinado naturalmente en la estructura de la administración de justicia regia, que era entre otras cosas utilizado para controlar el acceso a la exención nobiliaria por su transcendencia hacendística, podía verse acompañado en sus decisiones por unos oficiales que si bien de manera efectiva soportaban el funcionamiento de la Cancillería ${ }^{52}$, además igualmente poseían competencias jurisdiccionales en materias mayoritariamente económicas. La relación de los notarios con los pleitos de hidalguía está en primer lugar fundada en su función de libramiento de cartas, pero ya desde el siglo XIV poseen competencia jurisdiccional sobre asuntos de rentas, de la que en apelación resolvían los oidores, lo cual los relaciona aún más con las causas de hidalguía cuando se vieran en la Corte pleitos de esta materia que estuviesen motivados por prendas o repartimientos de cualesquier tipo de pechos ${ }^{53}$. Y consta esta relación tanto de la fazaña de Alfonso XI en donde se acusa a los notarios, junto a los alcaldes de los hijosdalgo y a los procuradores, de querer atraer los pleitos de hidalguía a la Corte rompiendo la tradición ${ }^{54}$, como de noticias de pleitos que se han conservado del reinado de Enrique II en los que sentencian los notarios junto a los alcaldes de los hijosdalgo, así lo hace, por ejemplificar, Pero Bernalt, notario de Castilla, en 1376: "E sobre esto amas las dichas partes çerraron rasones e pidieron sentençia, e los dichos Diego Fernandes, nuestro alcalle, e el dicho Pero Bernalt, notario, vista la dicha querella e la dicha respuesta e los dichos de todos los dichos testigos e la dicha sentençia que el dicho Gonçalo Alfón auía presentado, auido su acuerdo sobre ello, fallaron que el dicho Gonçalo Alfón que prouó bien su entençión en cómo es omne fijodalgo de padre e de auelo de quinientos sueldos" $" 55$.

${ }^{52}$ Martín Postigo, M. S. - Domínguez Rodríguez, C., La sala de los hijosdalgo de la Real Chancillería de Valladolid (Valladolid, Ámbito Ediciones 1990), p. 38; PAsCuAl Martínez, L., Aportación de la documentación murciana al estudio de los oficios de la Cancillería y de la Corte de Alfonso X el Sabio. Los oficios y los oficiales, en Miscelánea Medieval Murciana, 12 (1985), pp. 203-238, en especial p. 223.

${ }^{53}$ Pérez de la Canal, M. Á., La justicia, cit. (n. 27), pp. 426-27, Porras Arboledas, P. A., Los reinos occidentales, en Porras Arboledas, P. A. - Ramírez Vaquero, E. - Sabate i Curull, F., La época medieval: administración y gobierno (Madrid, ISTMO, 2003), p. 92.

${ }^{54}$ SuÁrez, F., La colección, cit. (n. 14), p. 592. Sin embargo de la ejecutoria de 1344 de Alfonso XI, ya reseñada, se decanta que aún en tiempos de este rey no conocían siempre los notarios, de forma permanente, salvo que se encontraran entre los "sabidores de fuero y de derecho" que sí asesoran al alcalde Día Sánchez de Rojas al sentenciar, en ARChG, Pergamino 106.

${ }^{55}$ ARChG, Pergamino 208. 
Importancia hacendística del pleito de hidalguía, reconocida por el rey, que impulsa a la Corona a que la ley más destacada dada sobre este asunto tras las de Enrique II y Juan I, la pragmática de Toro de 1398, no verse ya sobre cuestiones institucionales o de procedimiento sino relativas a inmunidades tributarias de los nobles. Enrique III viene a establecer el régimen de inmunidades de los pretendientes a hidalgo mientras que estuviesen pleiteando, así como, en otros casos concretos, las exenciones del resto de hidalgos: "Don Enrique, por la graçia de Dios, Rey de Castilla, [...] a los oydores de la mi Abdençia e a los mis alcaldes de los Fijosdalgo e a sus lugaresthenientese a los alcaldes e justiçias de todas las çibdades e villas e logares de los mis reygnos [...] sobre lo que mi merçed e voluntad es que aquellos que fueren notorios fijosdalgo e de solar conosçido e ovieren avido sentençia de cómo son dados por fijosdalgo segúnd el thenor de la ley del Ordenamiento que fizo el Rey mi señor e mi padre sobre esta razón, e después de la tal sentençia estovieron y están en posesyón de fidalguya que a estos tales que les sea guardada su franqueza e fidalguí. Eotrosy las mujeres que fueren casadas con fijosdalgo e mantovieren, después castidad, e sy la muger fidalga casara con ome que no sea fijodalgo mando que peche mientras biviere su marido, pero si muriere el marido, después de su muerte goze como fijadalgo. E mando que todos los otros pechen e paguen, non enbargante que trayan pleitos pendientes ante vosotros o ante alguno o algunos de vos, [...]. Dada en Toro a ocho dias del mes de agosto año del nasçimiento de nuestro Salvador Ihesu Christo de mil e tresientos e noventa e ocho años. Yo el Rey. Yo Pero González la fiz escrivir por mandado del nuestro señor el Rey" ${ }^{2}$.

Aspecto hacendístico de los pleitos de hidalguía que con el paso del tiempo fue relegando a las otras causas o hechos que podían motivar el inicio de semejantes pleitos a un segundo plano desde una perspectiva cuantitativa. Recordemos que $a b$ initio la simple negación de la hidalguía bastaba, pero, más allá, el sentir la hidalguía propia deshonrada también era suficiente motivo para iniciar un proceso, de ello es muestra la fazaña mencionada en la que Alfonso XI viene a sentenciar con los alcaldes de los hijosdalgo en su Corte, estante en Burgos, un pleito en donde la única causa era el deshonor presuntamente heredado del padre del querelloso: "Vino Johan Esteuanes de Safagun ante el dixol: "Sennor quando vos erades mosço et vos criaua la reyna Donna María, vuestra abuela, en Valladolid, don Garçia de Villamayor era Meryno Mayor de Castiella, et vino en Safagunt, et por conseio de enemigos de Esteuan Peres, my padre, et por algo quel dieron, prisool et enforcol seyendo omne fijodalgo, por los qual, Sennor, yo et mys hermanos andamos enbergonçados. Et Sennor, sea la vuestra merçed que mandedes que me resçiba a la prueba, que me quiero faser fijodalgo de padre et de abuelo et de quinientos sueldos" ${ }^{57}$.

Esta fazaña ejemplifica también que estos pleitos eran vistos en la Corte durante el bajomedievo, de lo que existen otras muchas evidencias, pero en ellos, como se acaba de referir, el inicio del pleito era ya por rentas en su inmensa mayoría. De esto da fe la ejecutoria de Enrique II, dada en Sevilla el 19 de abril de 1376, librada a petición del vecino de Medellín Gonzalo Alfón que está dirigida al concejo de

\footnotetext{
${ }^{56}$ ARChG, Caja 4493, pz. 67, incluida en NR. 2,11,9 y Nov. R. 11,27,2.

${ }^{57}$ SuÁrEZ, F., La colección, cit. (n. 14), p. 591.
} 
donde era vecino el hidalgo, pero también "a qualquier o qualesquier que cogen $o$ recabdan o tratan de coger o de enpadronar en renta o en fieldat o en otra manera qualesquier las monedas e pechos e derechos que los de nuestra tierra nos ounieren a dar o a pechar o los nos enviamos demandar o que vos el dicho conçejo de Medellín echades e derramáredes entre vos en qualquier manera" ${ }^{8}$. Es más, en el pleito se afirma rotundamente que el hidalgo había acudido porque Medellín lo había apremiado a pechar y que ésta era la única causa que lo motivaba a comparecer ante el rey para lograr su justicia. Y de esto versó el pleito, pues el mismo procurador del rey lo que solicita abiertamente es que peche como los labradores pecheros: "Et el dicho Gonçalo Alfón querelló ante los dichos nuestros alcalle e notario, e dixo que él seyendo ome fijodalgo de padre e de auelo, de quinientos sueldos según fuero de Castiella, que los cogedores que recabdauan los nuestros pechos y en Medellin y vos el dicho conçejo de Medellín que lo apremiáuades que pechase en ellos e que le prendauan e doncauan todo quanto le fallauan por esta rasón no le guardando ni queriendo guardar las franquesas e libertades que an los otros omes fijosdalgo del nuestro señorí" 59 .

Ya con Juan I y sus sucesores es aplastante el número de litigios en los que se discute la hidalguía por razones económicas, tributarias, decayendo ostensiblemente otras motivaciones, como se desprende de la documentación conservada. El mismo Gonzalo Alfón vio molestada, de nuevo, su hidalguía por el concejo de Medellín en 1380, reinante Juan I. El concejo volvió a argüir y defender la pechería de Alfón aprovechando la revisión de las sentencias de tiempos de Enrique II por parte de los oidores como había ordenado su sucesor, y la finalidad del concejo no es otra que pechase el pretendido, y ratificado por los alcaldes en 1376, hidalgo: "Bien sabedes en cómo enbiamos manera a vos el dicho conçeio de Medellín que todos los que fueran dados por fijosdalgo por sentençias en la Corte del rey don Enrique, nuestro padre que Dios perdone, de dies años acá por el su alcalle de los fijosdalgo e notario e con el su procurador que era a la sasón, que paresciesen en la nuestra Corte ante los oidores de la nuestra Abdiençia con las sentençias que en esta rasón tenían del dia que la dicha nuestra carta vos fuese mostrada fasta dos meses a lo mostrar e que a este dicho plaso enbiásedes vuestro procurador para que guardase vuestro derecho en la dicha rasón e dixiese contra las dichas sentençias lo que de esto quisiese... Contra lo qual Esteuan Sanches, procurador dende el dicho conçeio de Medellín dixo que la dicha carta de sentençia que el dicho Gonçalo Alfón presentara ante los dichos oydores que non valie ni fasía prueua alguna [...] por ende que non era pasada en cosa judgada ni aprouechaua al dicho Gonçalo Alfón para se escusar de las monedas, pechos e trebutos $e$ de los otros pechos e derechos que uos el dicho conçejo de Medellin entre vos echades e derramades... mandándole que pechase en todos los pechos reales e conçejales segunt que solian pechar e pagar aquellos donde él venie" ${ }^{60}$.

Igual ocurre bajo Enrique III, Juan II o Enrique IV: se consolida abrumadoramente como casi única causa que mueve a pleito de hidalguía el avasallamiento de las franquezas nobiliarias por parte de recaudadores del rey o concejiles, quedando desbancadas otras motivaciones por la realidad de los nuevos tiempos en una

\footnotetext{
${ }^{58}$ ARChG., Pergamino 208.

${ }^{59}$ Ibíd.

${ }^{60}$ ARChG, Pergamino 209.
} 
evolución que por otra parte ya estaba iniciada cuando menos bajo Alfonso XI ${ }^{61}$. Sirva como colofón de esta ejemplificación el extracto del inicio de la ejecutoria de Juan II dada en Tudela de Duero el 16 de octubre de 1426 en favor de Alonso Sánchez Ferrezuelo y sus hermanos Juan Alfonso y Diego Alfonso, librada contra el concejo de Casas de la Reina: "Don Johan, por la graçia de Dios, rey de Castilla [...] al conçeio e alcalles e alguasiles e otras justiçias e ofiçiales qualesquier de las Casas de Reyna, lugar de la encomyenda de Reyna e del maestradgo de Santiago a todos los conçejos e corregidores e alcalles e otras justiçias e ofiçiales qualesquier de todas las çibdades e villas e lugares de mis regnos e sennorios que agora son o serán de aqui adelante e a qualquier o qualesquier que cogen e recabdan o ayan de coger e de recabdar e de empadronar [...] las mis monedas e pedidos e de los otros pechos e tributos [...] sepades que pleyto pasó en la mi Corte ante Johan Arias, bachiller en leyes, e Garçía Sanches de Olmedo, liçençiado en decretos, mis alcalles de los fijosdalgo, e ante el dottor Ruy Garçía de Villalpando, mi notario del regno de León, el qual dicho pleito era entre Alfonso Sanches Ferresuelo e Johan Alfonso e Diego Alfonso, sus hermanos [...] sobre rasón de demanda que [...] fue puesta contra el dicho mi procurador fiscal e contra el procurador de dicho conçejo en dixo que él e los dichos sus hermanos siendo ommes fijosdalgo [...] que el dicho conçejo e alcalles e ommes buenos del dicho lugar de Casas de Reyna e otros por su mandado [...] que los enpadronaran e fisieran enpadronar con los pecheros" ${ }^{2}$.

\footnotetext{
${ }^{61}$ Como lo atestigua la ejecutoria de 1344, en ARChG, Pergamino 106, y de lo que son otros ejemplos la ejecutoria de 19 de diciembre de 1395, dada en Madrid, en el pleito de hidalguía de Gonzalo de la Torre de la Chancillería de Valladolid, véase: Varona García, M. A., Cartas ejecutorias del Archivo de la Real Chancillería de Valladolid (1395-1490) (Valladolid, Universidad de Valladolid, 2001), p. 25; o las cartas de Juan II de 22 de diciembre de 1423 relativa a la nobleza de Martín Tirado y la de 28 de febrero de 1427 de la hidalguía de Domingo Vicente, "Sepades que Martín Tirado, vezino de la dicha çibdad de Murçia, morador en la collaçión de Sant Olalla de la dicha çibdad se me enbio querellar, e dize quel es ome fijodalgo de padre e de aunelo, e de vegar quinientos sueldos, segund fuero de Castilla... que agora nueuamente vos el dicho conçejo e enpadronadores e cojedores e arrendadores e recabdadores por lo enguixar, e desenrrar, e le fazer mal, e daño, e le crebantar la dicha su ançesyon, e posesyon de fidalguía que le enpadronariades, $e$ fariades, e mandariades enpadronar, e poner en los padrones de algunos pechos", en ABELLÁN PÉREZ, J., Documentos de Juan II (Murcia-Cádiz, Academia de Alfonso X el Sabio - CSIC, 1984), pp. 227-229 y 331-333. Igualmente son ejemplos de esto: la ejecutoria de hidalguía de Enrique III dada en Valdemoro el 22 de enero de 1400 a favor de Fernando Martín Pelayes, vecino de Huete; la ejecutoria de hidalguía de Juan II dada en Valladolid el 30 de enero de 1431 a favor de Fernán Sánchez Abarca, vecino de Navalón, en ARChG, Pergamino 8; la ejecutoria de hidalguía de Juan II dada en Segovia el 18 de mayo de 1433 a favor de Pedro López de Soto, vecino de Cuenca, en ARChG, Pergamino 18; la ejecutoria de hidalguía de Juan II dada en Segovia el 18 de mayo de 1433 a favor de García y Martín Fernández de Soria, vecinos de Cuenca, en ARChG, Pergamino 254; la ejecutoria de hidalguía de Juan II dada en Tordesillas el 30 de mayo de 1448 a favor Gíl Díaz, vecino de Huete, en ARChG, Pergamino 242; la ejecutoria de hidalguía de Juan II dada en Fuentesauco el 28 de enero de 1450 a favor de Álvaro de Jerez, vecino de Jerez de Badajoz, en ARChG, Pergamino 139; o la ejecutoria de hidalguía de Enrique IV dada en Valladolid el 16 de septiembre de 1456 a favor de Hernando de la Cárdcel, vecino de Requena, en ARChG, Pergamino 131; etc.

${ }^{62}$ ARChG, Pergamino 44.
} 


\section{CONCLUSIONES}

En definitiva, el alcalde o los alcaldes de los hijosdalgo, dos con Alfonso X, ignoramos cuántos con Sancho IV y Fernando IV, dos con Alfonso XI, uno con Pedro I y quizás con Enrique II y dos con Juan I en adelante, tendrán competencia en los pleitos de hidalguía, cuando menos, desde el reinado de Alfonso XI, de lo que ha quedado constancia tanto por fazañas como por pleitos conservados. Pleitos de hidalguía que conocen por razón de la materia, dado que ambas partes pueden ser pecheras si a la postre el pretendido hidalgo es dado por villano y que en toda forma ha de probar una nobleza que en inicio se le niega. Y partes que igualmente, desde Alfonso XI, consisten en el demandante de la hidalguía, o demandado en su hidalguía, y el procurador del rey, el que en el caso de que el hidalgo sea el demandante ocupará la función de reo demandado que se opone a la nobleza del pretendiente, como la documentación de Alfonso XI pero sobre todo de Enrique II y sus sucesores atestiguan. Partes a la que se añade desde Juan I -lo avala la ley y práctica- el procurador del concejo, también negando la hidalguía, actor sobresaliente junto al fiscal que está destinado a ser garante de la veracidad de los dichos de los testigos, por su cercanía a ellos, así como más directo interesado en ganar la pechería del hidalgo, con la finalidad de contar entre sus vecinos una nueva cabeza más sobre la que repartir cualquier tipo de carga o imposición.

Proceso del que conocen los alcaldes de los hijosdalgo pero que pronto comparten con los notarios de provincia de la Corte como se decanta de una fazaña de Alfonso XI, si bien los pleitos vistos de este reinado no corroboran, aunque tampoco desmienten, la participación de los últimos en el acto de juzgar. Participación jurisdiccional, la de los notarios de provincia, que sí es un hecho documentalmente aquí probado desde Enrique II y que perseverará en el tiempo hasta el siglo XVI.

Alcaldes de los hijosdalgo que paulatinamente gozan de una mayor vis atractiva sobre los pleitos de hidalguía conforme avanza la baja Edad Media y el aparato de poder monárquico, y dentro de él la administración de justicia con las nuevas Audiencia y Corte, va tomando renovados bríos bajo Enrique II y Juan I. Atracción motivada por las disposiciones normativas regias, pero también por la misma casuística del pleito de hidalguía que cada vez en mayor medida posee como origen extraprocesal, en principio abierto, la disputa entre partes sobre asuntos hacendísticos, tributarios, lo que lo hace merecedor de la máxima atención por parte de una Monarquía cada vez más necesitada de ágiles recursos monetarios.

Y Alcaldes de los hijosdalgo que gozarán de una relativamente abundante legislación durante toda la baja Edad Media, de entre la cual será la de Enrique II y Juan I la que resulte elegida por los recopiladores del fin del medievo e inicios de la modernidad para crear el fundamento del cuerpo legal que regirá esta magistraturas y su marco de actuación, hasta el fin del Antiguo Régimen. Normativa que tiende hacia la exclusiva competencia para los alcaldes de los hijosdalgo de los pleitos de hidalguía, la cual prescribe, como así fue durante parte de la Edad Moderna.

Pero existe igualmente otra realidad histórica que corre pareja y en lid con 
la actividad de los alcaldes de los hijosdalgo y notarios y ésta no es otra que el conocimiento de los pleitos de hidalguía por las justicias ordinarias, locales o señoriales, en virtud de la costumbre, de lo que hay certeza tanto por la normativa consuetudinaria como por las sentencias que han llegado hasta nosotros.

Por tanto, esa inmemorial competencia privativa que poseyeron los alcaldes de los hijosdalgo sobre los pleitos de hidalguía que defienden los teóricos, los tribunales y los prácticos de la Edad Moderna y, lo que es más, la ley recopilada, no fue tal durante el bajo Medievo castellano. Desde cuando menos Alfonso $\mathrm{XI}$ conocen estos alcaldes de los pleitos de hidalguía, pero igualmente desde ese reinado y con seguridad desde el siguiente, con Enrique II, la compartieron cumulativamente con los notarios de provincias, esto en la Corte, pues por lo que respecta al conjunto del reino tuvieron que competir los alcaldes de los hijosdalgo con las otras justicias, señoriales y locales o pertenecientes a otras instituciones, que igualmente conocieron de los pleitos de hidalguía, siguiendo estos últimos una corriente que se adentra en la realidad consuetudinaria castellana.

Que los reyes desde Enrique II y Juan I atrajeran para sí en exclusiva y reiteradamente los pleitos de hidalguía, para la Corte, responde al fortalecimiento de la Monarquía y al interés que siempre tuvieron estas materias para la Corona, y esto más aún cuando el pleito de hidalguía se convierte cada vez más, por la causa metajurídica que lo provoca, en un proceso estrechamente relacionado con el ámbito tributario y fiscal. Otra cosa, y esto pese al Ordenamiento de Alcalá y a su ley primera del título veintiocho, es que los intentos y mandatos de los reyes para que los únicos que sentenciaran estos pleitos fueran los alcaldes de los hijosdalgo se cumplieran estrictamente. Los alcaldes de los hijosdalgo entienden pero las otras justicias también, cada uno con su legitimidad y todos creando efectos jurídicos, social y legalmente reconocidos por el conjunto del reino castellano. Sólo la progresiva vitalidad y robustez de la Corona, que como se sabe se consiguió a través de un proceso que fluye por los siglos XIV, XV y XVI, permitió que las disposiciones sobre los pleitos de hidalguía de Enrique II y Juan I abandonaran cierta virtualidad para convertirse en realidad, periplo en el que tendrán una función sobresaliente los Reyes Católicos, su legislación, en especial la pragmática de Córdoba de 1492, y también, con igual o mayor importancia, su administración de justicia y su práctica, con unas Chancillerías, ya dos, cada vez más poderosas en detrimento de las actuaciones de las demás justicias. 


\section{ApÉNDICE DOCUMENTAL ${ }^{*}$}

\section{Documento $\mathrm{N}^{\circ} 1$}

1344, marzo, 29, Algeciras

Carta ejecutoria de hidalguía de sentencia dada por el alcalde de los hijosdalgo Día Sanchez de Rojas, expedida en nombre de Alfonso XI, dirigida a la ciudad de Sevilla, en favor de la nobleza de Juan Fernández de Ahumada, vecino de dicha ciudad, a la colación de Santa María Magdalena.

ARChG, "Pergamino" No 106.

"Don Alfonso, por la graçia de Dios, rey de Castilla, de Toledo, de León, de Gallisia, de Seuilla, de Córdoua, de Murçia, de Jahén, del Algarbe e de Al-/gesiras e sennor de Molina e de [...] a qualesquier que ayan de enpadronar e de cojer e de recabdar en la muy noble çibdad de Seuilla, en su término, e / en las otras çibdades e villas e logares de nuestros regnos, en renta o en fialdat o en otra manera et que agora e de aquí adelante, los pechos que los de nuestra / tierra nos ouieren de dar e de pechar en qualquier manera o a qualquier o qualesquier de uos que ésta nuestra carta viéredes o el traslado de ella signado de escriuano pú-/ blico, salud e graçia. Sepades que se presentó en la nuestra Corte en juisio ante Día Sanches de Rojas, nuestro alcalle de los fijosdalgo de los nuestros reynos, Johan / Fernandes de Fumada, fijo de Aluaro Ruys de Fumada e vesino en la dicha çibdat a la collaçión de Santa María Magdalena en el de [...] por sy de la una parte / et Johan Sanches de Castro auido por nuestro procurador sustituto fecho por Ruy Martines de Santandrea, de la nuestra cámara, nuestro procurador en nuestro nonbre, de la otra parte, / en rasón de demanda que el dicho Johan Fernandes puso ante el dicho Día Sanches, nuestro alcalle, contra el dicho Johan Sanches, nuestro procurador en nuestro nonbre, et en recontado / el fecho dixo que él seyendo omme fijodalgo de padre e de abuelo e de quinientos sueldos, que los cojedores que cojen e recaudauan los nuestros pechos que le demandauan que pechasen ellos e que le / prendauan e tomauan lo que le fallauan por esta rasón non le guardando el preuillegio e franquesas e libertades que an los fijosdalgo de nuestro sennorío et pidió a dicho Día Sanches, nuestro / alcalle que por su sentençia pronunçiase, declarase, ser omme fijodalgo, et que por esta misma sentençia mandase al dicho Johan Sanches, en nuestro nonbre, que de aquí adelante los nuestros / cogedores que ouieren de coger e de recabdar los nuestros pechos que le non demandasen en pecho nin pechos, en ninguna manera que fuese, nin le costrinieren ellos pagar, porque era omme fijo-/dalgo commo dicho auía et que le guardasen el preuillegio e franquesas e libertades que an los otros fijosdalgo del nuestro sennorío, et otro sy que dieren e entregasen todo lo que por esta rasón le era sacado por los nuestros pechos o por alguno de ellos, por nuestras cartas e por nuestro mandado. Contra la qual demanda en respondiendo a ella el dicho Johan

* En las siguientes transcripciones se ha puntuado y acentuado para una mejor comprensión del texto. La "v" con valor de "u", vocal, ha sido transcrita por "u". Se han desarrollado todas las abreviaturas y las dobles letras han sido respetadas. Las líneas ilegibles por rotura del documento han sido salvadas con [...]. El fin de los renglones está señalado por /. 
Sanches, nuestro / procurador en nuestro nonbre, dixo que non sabía nin creya que el dicho Johan Fernandes fuese omme fijodalgo segunt que él desía. Et el dicho Johan Fernandes dixo que lo quería prouar et / pidió al dicho Día Sanches lo reçebiesen a la prueua, e el dicho Día Sanches reçibiolo a la dicha prueua, e preguntole que do auía los testigos para lo prouar. Et el dicho / Johan Fernandes dixo que en la nuestra Corte et pidió al dicho Día Sanches, nuestro alcalle, que le diese plaso en que los presentase ante él. Et el dicho Día sanches dió los plasos que de / fuero e de Derecho lo deuía dar segunt huso e estilo de la nuestra Corte para en que le presentare ante él los testigos que auía en la nuestra Corte, en esta rasón, apro-/uar con testigos fijosdalgo commo labradores. En los quales plasos el dicho Johan Fernandes presentó ante el dicho Día Sanches, nuestro alcalle, por testigos para prouar su entençión estando delante el / dicho Johan Sanches, nuestro procurador, por ommes que son fijosdalgo a Gonçalo Ruys de Fumada, fijo de Johan Ruys de Fumada, et a Johan Ruys de Amaya el / [...] Gutierre de Escalada, escudero de Garsy Laso, et por ommes ca dis que son labradores a Johan Lopes de Rebolledo de Fumada et a Johan / Gil, de Ordonno Çerio de Fumada. et tomaron por fieles a Johan Fernandes de Villacrus e a Fernand Peres de Hamusco. et tomaron por sobrefiel a Benito Fernandes de Liéuana. / et el dicho alcalle mandó a los dichos fieles e sobrefiel que fuesen con los dichos testigos a do estaua el alcalle e que les tomasen jura por el dicho alcalle en la / crus e santos euangelios segunt forma de Derecho e segunt fuero de Castilla. E de lo que los dichos testigos dixesen que lo uiesen los dichos fieles re-/contado ante él et ellos. Conpliéronlo e fisyéronlo todo asy et el dicho Johan Fernandes pidió al dicho nuestro alcalle que fisisiese leer y publicar ante sy los dichos de ellos / en fas de las dichas partes et en ellos fallaría en que prouaua su entençión en commo era omme fijodalgo segunt que se acabado auía de prouar, et que la diese por / bien prouada e que le mandara dar nuestra carta para que le ualiese e fuese guardado el preuillejo e franquesas e libertades que auían los otros ommes fijosdalgo del nuestro sennorío. / Contra lo qual el dicho Johan Sanches, nuestro procurador en nuestro nonbre, dixo lo que quiso de su derecho porque el dicho Johan Fernandes nodeuía auer la dicha nuestra carta / que pedía et pidió al dicho Día Sanches que lo diese por nuestro pechero. Sobre lo qual amas las dichas partes contendieron en juysio ante le dicho Día Sanches et / dixeron e rasonaron ante él todo lo que desir e rasonar quisieron de su derecho fasta que ençerraron rasones e le pidieron sentençia al dicho Día Sanches, nuestro alcalle. Visto la dicha demanda que el dicho Johan Fernandes fiso contra el dicho nuestro procurador en nuestro nonbre e la negaçion que de ellas fiso el nuestro procu-/rador e los dichos de los testigos que el dicho Johan Fernandes ante él sobre esto presentó e todas las otras rasones que sobre esto amas las dichas partes ante él / quisieron desir e rasonar de su derecho fasta que ençerraron rasones e le pidieron sentençia auido e requerido su ofiçio, visto con otros ommes letrados / sabidores de fuero e de derecho, fallo: que el dicho Johan Fernandes que prouó bien su entençión en commo es omme fijodalgo segunt que se obligó a prouar, diola / por bien prouada e judgó por sentençia e mandó que le valiese e fuese guardado el preuillejo e franquesas e libertades que an los otros ommes fijosdalgo del / nuestro sennorío 
e mandole dar esta nuestra carta en esta rasón. Porque vos mandamos vista esta nuestra carta o el traslado de ella signado commo dicho es que de-/fendades e anparades al dicho Johan Fernandes en el priuillejio e franquesas e libertades que an los otros ommes fijosdalgo del nuestro sennorío e que le no pongades en / los padrones de los mis pechos nin de ninguno de ellos ni le demandedes nin le prendedes nin [...] enbargades ninguna cosa de lo suyo por los dichos pechos / nin por alguno de ellos, saluo en los pechos que pecharen los otros ommes fijosdalgo del nuestro sennorío. Et por alguna cosa le auíades tomado e enbargado / por esta rasón que gelo dedes e entregades e desenbargades luego, bien e conplidamente en guisa que le non mengüe por ninguna cosa. E non fagades ende / al so pena de çient marauedís de la moneda nueua a cada uno de vos et por asy faser e conplir non lo quisiéredes, mandamos al conçeio e a los alcalles e alguasil de la / dicha çibdat de Seuilla e a todas las otras çibdades e alcalles e jurados, jueses e justiçias, merinos, alguasiles, maestres, priores, comendadores e soscomen-/dadores, alcaydes de los castillos e a todos los otros ofiçiales e aportellados de las çibdades e villas e logares de los mis regnos que agora y son e serán / de aquí adelante e a qualquier o a qualesquier que esta nuestra carta uieren o el traslado de ella signado commo dicho es que vos lo fagan asy faser e conplir e non / fagades ende al so la dicha pena a cada uno. Et de commo esta nestra carta vos fuere mostrada o el traslado de ella signado como dicho es e la con-/pliéredes mandamos so la dicha pena a qualquier escriuano público que para esto fuese llamado que dé ende a quien vos la mostrare testimonio signado / con su signo porque nos sepamos en commo se cunple esto que nos mandamos e non faga ende al so la dicha pena. Et de esto le mandamos / dar esta nuestra carta sellada con nuestro sello de plomo la carta leyda, dárgela. Dada en la villa de Algesira veynte e nueue días de março / era de mill e tresientos e ochenta e dos annos. / Por onra de verdat" (Firma ilegible).

\section{Documento $\mathrm{N}^{\circ} 2$}

1376, abril, 19, Sevilla

Carta ejecutoria de hidalguía de sentencia dada por el alcalde de los hijosdalgo Diego Fernández de Castro y el notario de Castilla Pero Bernalt, expedida en nombre de Enrique II, dirigida a la villa de Medellín, en favor de la nobleza de Gonzalo Alfon, vecino de dicha villa.

ARChG, "Pergamino" 208.

"Don Enrique por la graçia de Dios, rey de Castiella, de Toledo, de León, de Gallisia, de Seuylla, de Córdoua, de Murçia, de Jahén, del Algarbe, de Algesira e sennor de Molina, al conçejo, a los alcalles e alguasil de Medellín, e a qualquier o qualesquier que cogen o recabdan/ o ayan de coger o de enpadronar en renta o en fialdat o en otra manera qualesquier las monedas e pechos e derechos que los de la nuestra tierra nos ouuieren a dar o a pechar o los nos enviaremos demandar o que vos el dicho conçejo de Medellín echades /e derramáredes entre vos en qualquier manera que agora son o serán de aquí adelante et a qualquier o qualesquier de uos a quien ésta nuestra carta fuere mostrada o el traslado de ella signa- 
do de escriuano público sacado con abtoridat de jues o de alcalle, salud / e graçia. Sepades que paresçieron en juysio en la nuestra Corte ante Diego Fernandes de Castro, nuestro alcalle de los fijosdalgo en logar de Johan Martines de Rojas, e ante Pero Bernalt notario de Castiella, Gonçalo Alfón, fijo de Johan Alfón, vesino de y de / Medellín por sí, de la una parte, e Rodrigo Alfon de Duennas, nuestro pocurador en nuestro nonbre, de la otra parte. Et el dicho Gonçalo Alfón querelló ante los dichos nuestros alcalles e notario, e dixo que él seyendo omme fijodalgo de padre e de /auelo de quinientos sueldos según fuero de Castiella que los cogedores que recabdauan los nuestros pechos y en Medellín y vos el dicho conçejo de Medellín que lo apremiáuades que pechase en ellas e que le prendauan e doncauan todo quanto / le fallauan por esta rasón, non le guardando nin queriendo guardar las franquesas e libertades que en los otros ommes fijosdalgo del nuestro sennorío e pedió a los dichos nuestros alcalles e notario que librasen sobre ello lo que fallasen por Derecho. / Que si el dicho nuestro procurador lo negase que non era omme fijodalgo que él que lo quería prouar e que presentaua luego en prueua de su entención una sentençia signada de escriuano público e un proçeso de testigos çerrados que fueron / resçebidos sobre la dicha rasón y en Medellín, en la qual sentençia y proçeso se contenía que el dicho Gonçalo Alfón que contendiera sobre la dicha rasón y en Medellín con don Samuel de Castro, sobre rasón de las seys monedas que nos fueron / otorgadas en Toro este anno de la era de mill e quatroçientos e trese annos e que presentara por testigos a prueua de su entençión ante Fernant Péres, alcalle de y de Medellín, a Fernando Dias de Çea e Aluar Fernandes, alcalle de / y de Medellín, e a Fernand Rodrigues de Magarines e a Johan Sanches de Sandoual e a Esteuan Sanches, sobrino de Martín Martines, e a Diego Fernandes de Maçuelo, criado del dicho Johan Sanches de Sandoual, e a Vasco Lopero Guedoy. E que fue / y dado por quanto el dicho Gonçalo Alfón que non pagase las dichas monedas por la dicha sentençia. E luego el dicho nuestro procurador dixo que segund las condeçiones en que nos mandáramos arrendar las dichas monedas, que el dicho Gonçalo Alfón que non podría faser la dicha prueua y en Medellín e que non sabía nin que dijera que fuese ome fijodalgo, que lo negaua. E luego el dicho Gonçalo Alfón dixo que lo quería prouar e pedió a los dichos nuestros alcalle e notario / que lo reçebiesen a la dicha prueua, et los dichos nuestros alcalles e notario reçebiéronlo a la dicha prueua e preguntáronle do auía los testigos para la prueua. Et el dicho Gonçalo Alfón dixo que los auía aquí en la nuestra Corte e pe-/dióles que le diesen plasos conuenibles a que los troxese ante ellos. $\mathrm{E}$ los dichos nuestros alcalle e notario diéronle los plasos que de fuero e de Derecho lo deuían a dar segund uso e costunbre de la nuestra Corte. En los quales pla-/sos el dicho Gonçalo Alfón presentó por testigos en prueua de su entençión por escuderos fijosdalgo a Johan Gonsales, fijo de Johan Gonsales, vesino de y de Medellín e a Suero Gomes, fijo de Suero Gomes, vesino de Magasela, / et por labradores a Diego Fernandes, fijo de Johan Peres, vesino de Seuilla a la collaçión de Santa María Madanela, et a Lorenço Yannes, fijo de Johan Yannes de Medellín, vesino de Seuilla a la collaçion de Sant Miguell. De los quales testi- / gos los dichos alcalle e notario reçebieron jura fecha la sennal de la crus e los santos euangellios segund forma de 
Derecho, e reçebieron sus dichos de ellos. Et reçebidos de los dichos testigos amas las partes pedieron / a los dichos nuestros alcalle e notario que los fesiesen leer e publicar ante sí. E los dichos nuestros alcalle e notario a pedimiento de las dichas partes fisieron leer y publicar ante sí los dichos de los dichos testigos. E publicados / el dicho Gonçalo Alfón dixo que por todos los dichos de los dichos testigos e por la dicha sentençia que fallarían que era prouada conplidamente su entençión e pedió a los dichos alcalle e notario que la diesen por bien prouada. Et el dicho Rodrigo Alfón, nuestro procurador, dixo que commo quier que él conosía por escudero fijodalgo al dicho Johan Gonçales por quanto lo auía prouado en la nuestra Corte en su presençia, porque por él nin por / todos los dichos de todos los dichos testigos nin por la dicha sentençia que el dicho Gonçalo Alfón [...] que non se prouaua su entençión et pedió a los dichos alcalle e notario que la diesen por non prouada, / mandándole que pechase en todos los nuestros pechos segund que pechauan los labradores pecheros del nuestro sennorío. E sobre esto amas las dichas partes çerraron rasones e pidieron sentençia et los dichos Diego Fernandes, / nuestro alcalle, e el dicho Pero Bernalt, notario, vista la dicha querella e la dicha respuesta e los dichos de todos los dichos testigos e la dicha sentençia que el dicho Gonçalo Alfón auía presentado, auido su acuerdo sobre ello, /fallaron: que el dicho Gonçalo Alfón que prouó bien su entençión en commo es omme fijodalgo de padre e de auelo de quinientos sueldos, segund que se auía ofresçido a lo prouar, et dieron su entençión por bien prouada e man- / daron que le valiesen y le fuesen guardadas al dicho Gonçalo Alfón todas las franquesas e libertades que ouieron e an todos los otros ommes fijosdalgo del nuestro sennorío et que non es tenudo de pechar en pecho alguno / saluo en los pechos que pechan e pagan los otros ommes fijosdalgo del nuestro sennorío. Et juzgando por su sentençia pronunçiaronlo todo así e mandaron dar al dicho Gonçalo Alfón ésta nuestra carta sobre esta rasón. Porque / vos mandamos vista esta nuestra carta o el traslado de ella signado commo dicho es a todos e a cada unos de vos que guardades e cunplades e fagades guardar e conplir agora e de aquí adelante al dicho Gonçalo Alfón / todas las franquesas e libertades que ouieron e an los otros ommes fijosdalgo del nuestro sennorío e non le vaiades nin pasedes, nin consentades ir nin pasar contra ellas, nin contra parte de ellas en algund tienpo por qualquier manera. E otro sí que lo non pongades nin consentades poner en los padrones de los dichos pechos nin en alguno [...] suyo al dicho Gonçalo Alfón / por rasón de los dichos pechos nin por alguno de ellos, reales nin conçejales, saluo por los pechos e derechos que pagan e deuen pagar los otros fijosdalgo del nuestro sennorío, et si alguna cosa de lo suyo / le auedes o an prendado [...] que ge lo dedes e fagades luego dar e entregar, todo bien e conplidamente en guisa que lo non mengüe ende alguna cosa. E los unos nin los otros non faga-/des ende al por alguna manera, so pena de la nuestra merçed e de seysçientos marauedís de esta moneda a tal a cada uno de uos que si lo así faser e conplir non quisiéredes. Mandamos a todos los conçejos, alcalles, jurados, jueses, justiçias / merinos, alguasiles, maestres de las Órdenes, priores, comendadores e suscomendadores, alcaydes de los castiellos e casas fuertes e a todos los otros ofiçiales e aportellados de toda las cibdades e billas e logares /de nuestros regnos que agora son e serán 
de aquí adelante et a qualquier o qualesquier de ellos a quien esta nuestra carta fuere mostrada o el traslado de ella signado commo dicho es que anparen e guarden e defiendan al dicho / Gonçalo Alfón en todas las franquesas e libertades que an e deuen auer los otros ommes fijosdalgo del nuestro sennorío et uos lo fagan guardar, faser e conplir e non consientan que alguno nin algunos lo vuayan nin pasen contra / ellas nin contra parte de ellas algund tiempo por alguna manera. Et los unos nin los otros non fagan ende al so la dicha pena a cada uno. E de commo ésta nuestra carta les fuere mostrada e la cumpliredes mandamos so la- / dicha penna a qualquierescriuano que para esto fuere llamado que dé ende, al que vos la mostrare, traslado con su signo para que nos sepamos commo cunplides nuestro mandado [...] Dada en la / muy noble cibdat de Seuilla dies e nueue días de abril era de mill e quatroçientos e catorse annos, yo Johan Peres, escriuano del rey, la escriuí por mandado de Diego Fernandes, alcalle del rey e de los fijosdalgo (Firma y rúbrica). Pero Bernal, notario de Castiella" (Firma y rúbrica).

\section{Documento $\mathrm{N}^{\circ} 3$ \\ 1380 , s. 1 .}

Carta ejecutoria de hidalguía de sentencia dada por los oidores de la Audiencia del rey, expedida en nombre de Juan I, dirigida a la villa de Medellín, confirmando la sentencia dada por el alcalde de los hijosdalgo y notario de Castilla en 1376 sobre la nobleza de Gonzalo Alfón, vecino de dicha villa de Medellín.

ARChG, "Pergamino" 209.

"Don Johan, por la graçia de Dios, rey de Castiella, de Toledo, de León, de Galisia, de Seuilla, de Cordoua, de Murçia, de Jahén, del Algarbe, de Algeçira e señor de Lara e de Viscaya e de Molina al conçeio / de la villa de Medellín e a los cogedores e enpadronadores e recabdadores e pesquesidores que cogen e recabdan en renta o en fialdat o en otra manera qualesquier las monedas e los otros pechos / e seruiçios e trebutos qualesquier que nos ayamos de auer y en la dicha villa e en su término, e en todas las çibdades e villas e lugares de nuestros reynos este anno de la era de esta carta e de aquí adelante de cada anno o vos el dicho conçeio echáredes e derramáredes entre vos, e a todos los conçeios e alcalles e merinos, jurados, jueses, justiçias, algua-/siles, recabdadores et enpadronadores e pesquesidores de las dichas monedas e seruiçios e trebutos qualesquier que los de los nuestros reynos nos ayan a dar e a pechar e seruir en / qualquier manera, et a los maestres de las órdenes, priores, comendadores o suscomendadores, alcaydes de los castiellos e casas fuertes et a todos los otros ofiçiales e apor-/tellados de todas las çibdades e uillas e lugares de nuestros reynos que agora son o serán de aquí adelante, et a qualquier o qualesquier de uos a quien ésta nuestra carta fuere mos-l trada o el traslado de ella signado de escriuano público sacado con abtoridat de jues o de alcalle, salud e graçia. Bien sabedes en commo enbiamos mandar a vos el / dicho conçeio de Medellín que todos los que fueran dados por fijosdalgo por sentençias en la Corte del rey don Enrique, nuestro padre que Dios perdone, de dies annos acá por / el su alcalle de los fijosdalgo e notario e con el su procurador 
que era a la sassón, que paresciesen en la nuestra Corte ante los oidores de la nuestra Abdiençia con las sentençias que en esta / rasón tenían del día que la dicha nuestra carta vos fuese mostrada fasta dos meses a lo mostrar et que a este dicho plaso enbiásedes vuestro procurador para que guardase vuestro / derecho en la dicha rasón et dixiese contra las dichas sentençias lo que de esto quisiese. En el qual plaso de los dichos dos meses paresçió en juysio ante los dichos nuestros oydores / de la una parte Gonçalo Alfón, fijo de Johan Alfón, vesino de y de la dicha villa de Medellín, et de la otra parte Esteuan Sanches, vesino de la dicha villa de Medellín procura-/ dor de uos el dicho conçeio. Et el dicho Gonçalo Alfón presentó ante los dichos oydores una peteçión en que os fasía saber que agora podía aver quatro annos poco más o menos / acá que él que contendiera en la Corte del dicho rey nuestro padre, que Dios perdone, con el su procurador sobre rasón de su fidalguía por quanto dixo que él que es omme fijodalgo de / padre e de avuello de deuengar quinientos sueldos et que estando él en la dicha villa en posesión de fijodalgo de veynte años acá e más tienpo, porque algunos ommes de uos / el dicho conçeio de Medellín ponien en dubda su fidalguía por ende que ouiera de yr a la Corte del dicho rey nuestro padre a prouar su fidalguía ante el su alcalle de los / fijosdalgo que eran a la sasón e con el su procurador e que contendiera ante él fasta que el dicho su alcalle dio sentençia en el dicho pleito, en que fallara que era omme fijodalgo de padre e / de auello como dicho es, segunt que todo esto e otras cosas mejor e más conplidamente por la dicha carta de sentençia se conteníe. Que luego la presentó ante los dichos oydores et por qu-/anto nos fesiéramos el dicho ordenamiento, por ende que él que se veniera presentar con la dicha carta de sentençia de fidalguía en el tienpo que deuía ante los dichos oydores e pedioles que le man-/dasen dar nuestra carta para que le fuese guardada la dicha carta de sentençia del dicho rey nuestro padre, que Dios perdone, segunt que en ella se contenía. Contra lo qual Esteuan Sanches, procurador / dende el dicho conçeio de Medellín, dixo que la dicha carta de sentençia que el dicho Gonçalo Alfón presentara ante los dichos oydores que non valíe nin fasía prueua alguna por quanto dixo / que la prueua que él fesiera non fuera conplida segunt estilo de la nuestra Corte, ca deuiera prouar con tres testigos fijosdalgo e non prouara con alguno de ellos, ca dixo que los dichos / Suero Gomes e Johan Gomes que se llamaran fijosdalgo, que lo non eran en este tienpo nin lo eran agora, nin Dios lo quisiese, e niégogelo, et puesto sin su perjuysio del derecho de la su / parte que si ydalgo fueran, lo que non eran, que la dicha prouança que non fuera conplida segunt estilo de la nuestra Corte, ca dixo que todo aquel que quería prouar que es fijodalgo que deuía / prouar con tres testigos a lo menos que sean fijosdalgo et pues que la prueua non fuera fecha con tres testigos fijosdalgo, que asy la dicha sentençia non fuera dada commo deuíe, e / por ende que non era pasada en cosa judgada nin aprouechaua al dicho Gonçalo Alfón para se escusar de las monedas, pechos e trebutos e de los otros pechos e derechos que uos, el dicho con-/çejo de Medellín, entre vos echades e derramades, et pidió que por su sentençia defenetiua lo judgasen e mandasen todo asy. Et quando la dicha sentençia fuese dada sellendo guar-/dado el estilo de la nuestra Corte porque ella fuese alguna, dixo que non valdría por quanto los testigos en ella presentados 
deposieron mentira e falsidat por quanto deposieron que el dicho / Gonçalo Alfón que era omme fijodalgo de padre e de avuello, non seyendo ello asy verdat ca dixo el dicho Gonçalo Alfón que era pechero, fijo e nieto de pechero et que asy lo pro-/uaría sy mester le fuese, et pedió a los dichos oydores que por su defenitiua sentençia pronunçiasen la dicha sentençia ser ninguna, commo lo era, mandándole que pechase en todos los pechos / reales e conçejales, segunt que solían pechar e pagar aquellos donde él veníe, condenándolo en las costas derechas. Sobre lo qual las dichas partes dexieron de su derecho fasta que los / dichos oydores dieron sentençia en que fallaron que deuían resçebir e resçebieron a la prueua a amas las dichas partes, a la prueua a la parte del dicho Gonçalo Alfón a prouar commo es omme fijo-/dalgo de padre e de avuello, e a la prueua de uos, el dicho conçeio de Medellín, a prouar en commo el dicho Gonçalo Alfón era pechero e fijo de pechero. Et por quanto sy las dichas / partes ouieran a traer los testigos aquí a la nuestra Corte ante los dichos nuestros oydores para prouar sus entençiones resçebieran grandes dannos e fasieran grandes costas, mandaron que les de-/xiesen los lugares do uiuían los testigos para prouar sus entençiones e que les mandarían dar nuestras cartas de reçebtorías sobre la dicha rasón. Et por quanto la parte de uos, el dicho conçejo / de Medellín, fue dicho a los dichos oydores que non querían carta de reçebtoría sobre la dicha rasón, los dichos nuestros oydores mandaron dar nuestra carta de reçebtoría al dicho Gonçalo Alfón /sobre la dicha rasón para lugares çiertos contenidos en la dicha carta de reçebtoría et posiéronle plaso çierto a que troxiese e a presentase las prouanças, e ese mesmo plaso posieron a la / parte de uos el dicho conçeio a que les fuesedes ver presentar e jurar e conoser sy quisiese. En el qual plaso el dicho Gonçalo Alfón truxo e a presentó sus prouanças. Et a pedemiento de las / dichas partes fueron abiertas e publicadas e contendieron en juisio ante los dichos nuestros oydores fasta que açerraron raçones et pedieron sentençia. Et los dichos nuestros oydores dieron el / dicho pleyto por concluso e por ençerrado et posieron plaso para dar sentençia por día çierto e devido de Derecho, de cada día segunt uso e costunbre de la nuestra Corte. Et ellos visto el proçeso / del dicho pleito e todo lo en él contenido auido su acuerdo sobre todo fallaron que asy por la dicha carta de sentençia del dicho rey nuestro padre, que Dios perdone, que el dicho Gonçalo Alfón ante ellos pre-/sentara, commo por los testigos e prouanças que ante ellos truxiera e a presentara que prouara bien su entençión e diéronla por bien prouada. E la parte de uos, el dicho conçeio de Medellín, que / non prouastes lo que auíades a prouar e dieron vuestra entençión por non prouada. Et mandaron dar nuestra carta para que les sea guardada e conplida la dicha sentençia del dicho rey nuestro padre, que Dios perdo-/ne, segunt que en ella se contiene. Et judgando por su sentençia defenetiua pronunçiáronlo todo así. Porque uos mandamos vista esta nuestra carta o el traslado de ella signado commo dicho es a cada / uno de uos en vuestros lugares e juridiciones que veades la dicha carta de sentençia del dicho rey nuestro padre, que Dios perdone, que por parte del dicho Gonçalo Alfón vos será mostrada en la dicha ra-/són e guardar [...] e fasérlagela guardar e cunplir en todo bien e cunplidamente segunt como en ella se contiene. Et non fagades ende al por alguna manera, so pena de la nuestra merçed [...] e de 
seys [...] cada uno de uos. Et de commo ésta nuestra carta uos fuere mostrada [...] los otros la conpliéredes, mandamos so la dicha pena [...] los oydores del Abdençia del rey la mandaron $[. .$.$] ".$

\section{Documento $\mathrm{N}^{\circ} 4$}

1431, abril, 18, Segura (Jaén)

Carta de sentencia sobre la hidalguía de Gonzalo Vázquez, vecino de Arroyo Molinos, dada por don Lope Álvarez, comendador mayor de León de la Orden de Santiago, declarándolo libre de servir en el repartimiento de las monedas de 1429.

ARChG, "Pergamino" 92.

"Sepan quantos esta carta de sentençia vieren como en la villa de Segura, dies e ocho días del mes de abril anno del nasçimiento del nuestro Sennor Ihesu Christo / de mil e quatroçientos e treynta e un annos, ante el onrado sennor don Lope Aluares, comendador mayor de León, justiçia mayor en la dicha tierra de León, en presen-/çia de mí Johan Alfonso, escriuano de nuestro sennor el rey e su notario público en la Corte e en todos sus regnos, e de los testigos de yuso escriptos paresçió / Gonçalo Munnos, escriuano, vesino de la dicha villa, por abtor, e Gonçalo Vasques, vesino de Arroyo de Molinos, por parte de reo, e dixeron que al dicho sennor comendador / mayor que por quanto su merçet avía dado por jues a Myguell Sanches, veçino del Arroyo de Maestre, en un pleito que ellos an en uno sobre rasón de treçe monedas / que el dicho Gonçalo Munnos, escriuano, demandó al dicho Gonçalo Vasques del anno que pasó de mill e quatroçientos e veynte e nueue annos que el dicho Gonçalo Munnos / fue arrendador. Sobre lo qual dixeron que trabtaron pleito a tanto fasta que concluyeron e pidieron sentençia, el dicho abtor disiendo que el dicho reo le era deuido et / obligado a le dar e pagar las dichas trese monedas, e el dicho Gonçalo Vasques, reo, respondiendo que non avía porqué pagar las dichas monedas por ser omme fijo-l dalgo notorio e por estar en tal posesión, segund más largamente dixeron que en el dicho proçeso era contenydo. El qual dicho proçeso, luego los sobredichos, presentaron ante el dicho sennor comendador mayor, e así presentado las dichas partes pedieron al dicho sennor comendador mayor que tomase el conosçimiento del dicho pleito et / lo librase. E luego el dicho sennor comendador mayor dixo que a pedimiento de las dichas partes tomaua el conosçimiento del dicho pleito en el estado en que estaua, e que / mandaua a las dichas partes que digan lo que desir quisieren de su derecho cada una en su prouecho porque él librase el dicho pleito. E luego el dicho Gonçalo Munnos / dixo que se afirmaua en todo lo por él dicho en este dicho pleito e que concluya e pedía sentençia. E luego eso mesmo el dicho Gonçalo Vasques dixo que se afirmaua / en todo lo por él dicho e rasonado en este dicho pleito e que el dicho sennor comendador fallaría prouada su entençión así por los preuillejos en este dicho pleito / presentados, commo por los testigos suyos, como por el ser notorio fijodalgo e que le pedía pronunçiara e que sobre lo rasonado concluya e pedía las costas. Et / luego el dicho sennor comendador mayor dixo que havía el dicho pleito por concluso e 
las rasones de él por ençerradas por amas las dichas partes e que les asignaua / plaso para oyr sentençia para el miércoles primero que viene, a la abdiençia de la nona. E después de esto el dicho día miércoles dies e nueue días del dicho mes e / anno susodicho, estando el dicho sennor comendador mayor en abdiençia en esta villa do la acostunbra faser, presentes las dichas partes, dió esta sentençia / que se sigue: fallamos que segund los méritos de esta cabsa que el dicho Gonçalo Vasques prouó asas conplidamente su intento conuiene saber ser omme fijodal/ go por ende pronunçiamos su entençión por bien prouada sin embargo de la prueua que el dicho Gonçalo Munnos fiso, por la qual paresçe afirmar la prueua et / entinçión del dicho Gonçalo Vazques, e por esto e porque a nos es notorio el dicho Gonçalo Vazques ser fidalgo e estar en tal posesión, por ende asoluemos e / damos por quito al dicho Gonçalo Vasques de lo contra él pedido por el dicho Gonçalo Munnos e ponémosle silençio perpetuo que de aquí adelante más no le llame / en demanda ni en pleito sobre la dicha rasón et por çiertas rasones que a ello nos mueuen no fasemos condenaçión de costas. Mandamos que cada una de éstas / partes se pare a las que fiso. E judgando por esta nuestra sentençia definitiba así lo pronunçiamos e mandamos por estos presentes escriptos e por ellos. Dada / e pronunçiada fue esta sentençia en la dicha villa de Segura en el dicho dya e anno susodicho, en fas de las dichas partes, e así dada el dicho Gonçalo Vasques / dixo que consentía en ella e que pedía al dicho sennor comendador mayor que ge la mandase dar signada. Et luego el dicho Gonçalo Munnos calló. E el dicho I sennor comendador mayor mandó a mí el dicho escriuano que diese la dicha sentençia signada al dicho Gonçalo Vasques. Testigos que fueron presentes Diego Gonçales, escriuano, / e Alfón de Osuna e Matheos Miguell e Alfón Martín Serrano, e Alfón Lopes, alguasil. Va escripto sobre raydo o dis dies e ocho, non enpesca. E yo / el dicho Johan Alfonso escriuano e notario público sobre dicho del dicho sennor rey a todo lo que dicho es que en mi presençia pasó con los dichos testigos presente / fuy e esta carta por ruego e pedimiento del dicho Gonçalo Vasques fise escriuir e por tal fis aquí este mío signo a tal en testimonio / de verdat" (Signo del escribano y firma y rúbrica).

\section{BiBLIOGRAFÍA}

Abellán Pérez, J., Documentos de Juan II (Murcia - Cádiz, Academia de Alfonso X el Sabio - CSIC, 1984).

Alvarado Planas, J. - Oliva Manso, G., Los fueros de Castilla (Madrid, Centro de Estudios Políticos y Constitucionales, 2004).

ARCE De OTAlora, J. de, De nobilitatis et inmunitatis hispaniae causis (quas hidalguia appellant) de que regalium tributorum (quos pechos dicunt) iure, ordina, iudicio et excusatione summa (Granada, Xantus et Sebastianus Nebrissensis, 1553).

Ballesteros Beretta, A., Alfonso X el Sabio (Barcelona, Ediciones El Albir, 1984).

Colección de Cortes de los reynos de León y Castilla dada a la luz por la Real Academia de la Historia (Madrid, Imprenta de Marcelino Calero y Portocarrero, 1836).

Fernández de Ayala Aulestia, M., Práctica y formulario de la Chancillería de Valladolid (Valladolid, Imprenta de José de Rueda, 1667). Se usa aquí la edición corregida 
y aumentada de don José de Luyando, Zaragoza, Imprenta de Francisco Revilla, 1733.

García de SaAvedra, J., Tractatus de hispanorum nobilitate et exemptione sive ad pracmaticam cordvbensem (Alcalá de Henares, a costa de Juan de Sarria, 1597).

Garriga, C., La Audiencia y Chancillerías castellanas. (1371-1525). Historia política, régimen jurídico y práctica institucional (Madrid, Centro de Estudios Constitucionales, 1994).

GonzÁlez Jiménez, M., Alfonso X el Sabio, 1252-1284 (Palencia, La Olmeda, 1993).

Hevia Bolaños, J. de, Curia philipica (Lima, 1603). Se usa aquí la edición de Madrid, Oficina de Ramón Ruiz, 1797.

Jordan de Asso, I. - Manuel y Rodríguez, M. de, El Fuero Viejo de Castilla, sacado y comprobado con el ejemplar de la misma obra que existe en la Real Biblioteca de esta Corte y con otros manuscritos (Madrid, Señores de Calleja, 1847).

López Nevot, J. A., Práctica de la Real Chancillería de Granada. Estudio preliminar y edición del manuscrito 309 de la Biblioteca Nacional de Madrid, Granada (Granada, Comares, 2005).

Martín Postigo, M. S. - Domínguez Rodríguez, C., La sala de los hijosdalgo de la Real Chancillería de Valladolid (Valladolid, Ámbito Ediciones 1990).

Martín, J.L., Los fueros de la Orden de Santiago en Castilla-La Mancha, en Alvarado PlanAs, J. (coordinador), Espacios y fueros en Castilla-La Mancha (siglos XI-XV). Una perspectiva metodológica (Madrid, Ediciones Polifemo, 1995).

Menjot, D., Fiscalidad y sociedad. Los murcianos y el impuesto en la baja Edad Media (Murcia, Academia de Alfonso X el Sabio, 1986).

Moxó, S. de, La nobleza castellana en la Edad Media, en Moxó, S. de, Feudalismo, señorío y nobleza en la Castilla Medieval (Madrid, Real Academia de la Historia, 2000).

O'Callaghan, J. F., El rey sabio. El reinado de Alfonso X de Castilla (Sevilla, Universidad de Sevilla, 1999).

Orejón y Haro, A. de, Apuntamientos sobre la hidalguía y colección de fórmulas para todos los recursos de esta naturaleza, con la instrucción que debe dirigir los de los extranjeros, conforme a la práctica que observa la sala de los sres. alcaldes de los hijosdalgo de la Real Chancillería de Granada (Málaga, Luis de Carreras impresor, 1795). Se usa la siguiente edición Díaz de la guardia y López, L., La hidalguía a fines del Antiguo Régimen. Los “Apuntamientos" del granadino Antonio de Orejón y Haro: estudio y edición, en Espacio, Tiempo y Forma. Historia Moderna, 21 (2008).

Pascual Martínez, L., Aportación de la documentación murciana al estudio de los oficios de la Cancillería y de la Corte de Alfonso X el Sabio. Los oficios y los oficiales, en Miscelánea Medieval Murciana, 12 (1985).

Pascual Martínez, L., Documentos de Enrique II (Murcia, Academia de Alfonso X el Sabio - CSIC, 1983).

Pérez de la CAnal, M. Á., La justicia de la Corte de Castilla durante los siglos XIII al $X V$, en Historia. Instituciones. Documentos, 2 (1975).

Porras Arboledas, P. A., Los reinos occidentales, en Porras Arboledas, P. A. - Ramírez Vaquero, E. - Sabate i Curull, F., La época medieval: administración y gobierno (Madrid, istmo, 2003).

Rodríguez Fernández, J, Los Fueros del Reino de León, II: Documentos (Madrid, Ediciones Leonesas, 1981). 
Rodríguez Fernández, J, Los fueros locales de la provincia de Zamora (Salamanca, Junta de Castilla y León, 1990).

Salazar y Achá, J. de, La casa del rey de Castilla y León en la Edad Media (Madrid, Centro de Estudios Políticos y Constitucionales, 2000).

Salvador Martínez, H., Alfonso X el Sabio. Una biografia (Madrid, Ediciones Polifemo, 2003).

SÁnchez, G., Para la historia de la redacción del antiguo Derecho territorial castellano, en Anuario de Historia del Derecho Español, 6 (1929).

SuÁrez Verdeguer, F., La colección de "fazañas" del Ms. 431 de la Biblioteca Nacional, en $A H D E ., 14$ (1942-1943).

Valdeón Baruque, J., Alfonso X el Sabio (Barcelona, Ediciones Temas de Hoy, 2003).

Varona García, M. A., Cartas ejecutorias del Archivo de la Real Chancillería de Valladolid (1395-1490) (Valladolid, Universidad de Valladolid, 2001).

Varona García, M. A., La Chancillería de Valladolid en el reinado de los Reyes Católicos (Valladolid, Universidad de Valladolid, 1981).

VÁzQuez Campos, B., "Frontera" y adelantamientos en época de Alfonso X, en Historia, Instituciones, Documentos, 30 (2003).

Villapalos Salas, G. A, Justicia y monarquía. Puntos de vista sobre su evolución en el reinado de los Reyes Católicos: discurso leido el día 16 de junio de 1997 en su recepción pública como académico de número, por Gustavo Villapalos Salas, y contestación de José María Castán Vazquez (Madrid, Marcial Pons, 1997). 